\title{
Karst Geomorphology and Environmental Change
}

Link to publication record in Manchester Research Explorer

\section{Citation for published version (APA):}

Woodward, J. C., \& Lewin, J. (2009). Karst Geomorphology and Environmental Change. In The Physical Geography of the Mediterranean (1st ed., pp. 287-317). Oxford University Press.

\section{Published in:}

The Physical Geography of the Mediterranean

\section{Citing this paper}

Please note that where the full-text provided on Manchester Research Explorer is the Author Accepted Manuscript or Proof version this may differ from the final Published version. If citing, it is advised that you check and use the publisher's definitive version.

\section{General rights}

Copyright and moral rights for the publications made accessible in the Research Explorer are retained by the authors and/or other copyright owners and it is a condition of accessing publications that users recognise and abide by the legal requirements associated with these rights.

\section{Takedown policy}

If you believe that this document breaches copyright please refer to the University of Manchester's Takedown Procedures [http://man.ac.uk/04Y6Bo] or contact uml.scholarlycommunications@manchester.ac.uk providing relevant details, so we can investigate your claim.

\section{OPEN ACCESS}




\title{
10 \\ Karst Geomorphology and Environmental Change
}

\author{
John Lewin and Jamie Woodward
}

\section{Introduction}

Whilst about 12 per cent of the earth's dry and ice-free land is covered by carbonate rocks (limestone, marble, and dolomite), the proportion is significantly higher in the landscapes that border the Mediterranean Sea. These rock types are especially widespread in the northern part of the region and limestones in particular reach great thicknesses in Spain, southern France, Italy, the Balkan Peninsula, and Turkey and in many of the Mediterranean islands (Figure 10.1). Abundant precipitation in the uplands of the Mediterranean has encouraged solutional weathering of these carbonate rocks for an extended period. The region contains some of the deepest karst aquifers in the world, with many extending deep below present sea level (e.g. Bakalowicz et al. 2008). The regional fall in base level associated with the Messinian Salinity Crisis allowed the formation of very deep, multiphase karst systems in several parts of the Mediterranean basin (e.g. Mocochain et al. 2006). Thus, karst terrains and karstic processes are very significant components of the physical geography of the Mediterranean basin. Indeed, along with the climate and the vegetation, it can be argued that limestone landscapes (including limestone bedrock coasts) are one of the defining characteristics of the Mediterranean environment. Much of the northern coastline is flanked by mountains with bare limestone hillslopes (Figure 10.2) drained by short and steep river systems whose headwaters commonly lie in well-developed karst terrain. Karst terrains are also well developed in the Levant and in the Atlas Mountains of Morocco and Algeria, while relict karst features can be identified in the low-relief desert regions of Libya and Egypt (Perritaz 2004) (Figure 10.1). Mediterranean karst environments are also associated with distinctive soils, habitats and ecosystems as described in Chapters 5 , 6 , and 23.

The nature and evolution of the karst landscapes across the Mediterranean region displays considerable spatial variability due to contrasts in relief, bedrock composition and structure, climatic history, and other factors. The karst geomorphological system is distinguished from other systems (e.g. glacial, fluvial, coastal, and aeolian) because of the dominant role of dissolution which results in water flowing in a subterranean circulation system rather than in surface channels (Ford 2004). In different parts of the Mediterranean basin, however, glacial, fluvial, coastal, and aeolian processes have themselves also impacted significantly upon karst landscapes. It is possible, therefore, to identify a mosaic of Mediterranean karst landscapes. This mosaic includes both active and relict terrains; with each component operating within different boundary conditions (mainly reflecting variations in climate and relief) and each with a distinctive history. In favourable settings, the precipitation of carbonate minerals from karstic waters has also produced a highly distinctive suite of features and landscapes in the Mediterranean region. Another important feature of Mediterranean karst environments is the formation of distinctive depositional environments in caves and rockshelters where important records of long-term environmental change and prehistoric human activity have been preserved (Woodward and Goldberg 2001; Bar-Matthews et al. 1999).

It is also important to appreciate that limestone landscapes in the Mediterranean basin have exerted a profound influence on the imagination of humankind. For example, the legendary River Styx, issuing from the 


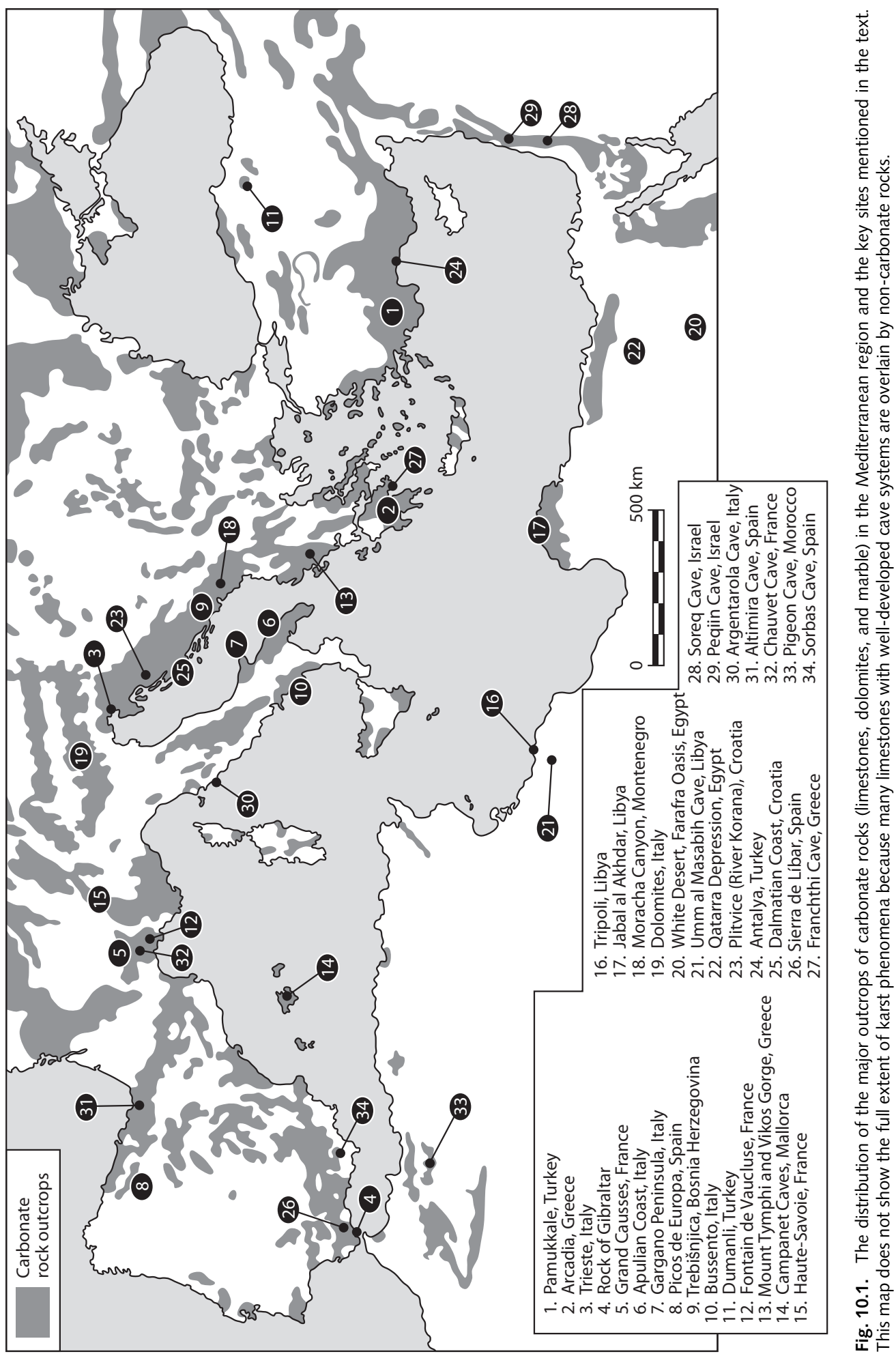




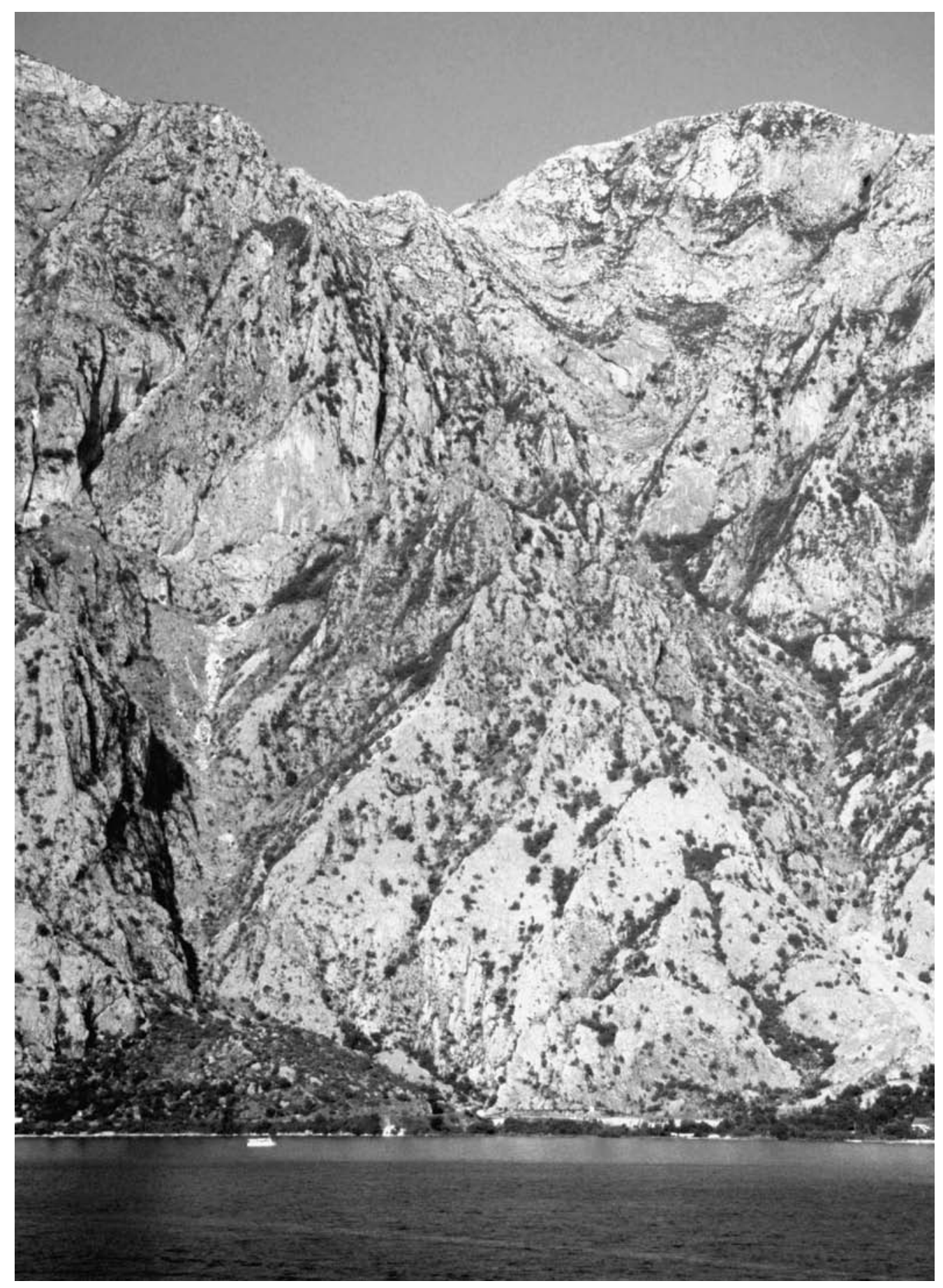

Fig. 10.2. Steep limestone slopes in Kotor Bay on the coast of Montenegro. Note the steep chute and channel system and alluvial/colluvial fan on the left ( photo: Jamie Woodward). 
Gates of Hell, was reputedly based on a small river in Arcadia, Greece, with waters so cold and venomous as to prove fatal to those that drank them (Brewster 1997). The wine of Arcadia was, according to Aristotle, liable to become chalky when heated in a goat's skin near a fire. Nearer our own time, such phenomena become comprehensible in terms of a developing understanding of snowmelt and sub-surface hydrology, stream water quality, and chemical dissolution processes affecting carbonate rocks. Ford and Williams (1989: 6) have described the Mediterranean as 'the cradle of karstic studies' because it was a Mediterranean limestone landscape in particular that gave enormous initial stimulus to scientific developments in geomorphology and karst studies.

\section{The Karst of Trieste}

It was the karst of Trieste, a small region in the Dinaric Alps near the Adriatic coast (Figure 10.1), that played a significant role in the development of landform sciences as the field setting for the first systematic investigation of the distinctive features that have become known as 'karst phenomena'. During his doctoral research in the karst, Jovan Cvijić, a student of Albrect Penck in Vienna, was able to observe connections between distinctive surface forms and sub-surface structures as exposed in the recently constructed railway cuttings along the line from Trieste to central Europe. His work Das Karstphänomen (1893) is generally seen as critical in focusing and developing karst studies (see Herak and Stringfield 1972; Ford and Williams 1989). In an era strong on nomenclature and classification, a byproduct was the incorporation of local Slovene words into the scientific geomorphological literature (e.g. polje, dolina, ponor, and uvala), sometimes in German translationindeed 'karst' is the German form of the Slovene 'kras'. With numerous prefixes, the German 'karren' is also used for types of solution microforms on limestone surfaces, another manifestation of the strong role of German-speaking scientists in developing karst studies. Significantly, there was an early and explicit consideration of process mechanisms, and especially of hydrology and dissolution chemistry, to a far greater extent than in most contemporary landform studies in the English-speaking world which, in the late nineteenth and early twentieth centuries, were especially dominated by long-term and large-scale evolutionary models (see Beckinsale and Chorley 1991). These, too, were applied to limestone landscapes under the influence of William Morris Davis (who visited the Trieste karst region in 1899) with the development of distinctive limestone erosion cycles.

\section{Karst Development}

In general terms, karst landforms characteristically develop on mechanically strong, but chemically soluble rocks with a high degree of secondary porosity — as occurs with massive limestones (and also dolomites) that are bedded, faulted, and jointed. The uplifted carbonate rocks that dominate the main mountain chains in the Mediterranean region display many of these characteristics (Figure 10.3). Primary (intergranular) porosity in these rocks is negligible, so that water movement takes place along voids that become enlarged over time to provide conduits for water, solutes, and sediments.

The hydrological cycle provides the primary source of energy for karst formation because water is the solvent that dissolves carbonate rocks and then carries the ions away in solution (Williams 2004). In broad terms, groundwater flows are driven by the difference in elevation (hydraulic gradient) between the recharge area and the discharge point or spring. Rates of bedrock dissolution are controlled by geochemical processes. In the karst system this is strongly dependent upon the extent to which the water has become acidified (by dissolved carbon dioxide) during its passage through the atmosphere, vegetation, and soil profile prior to coming into contact with the bedrock (ibid.). Each of the key karst-forming factors of hydraulic gradient, water flux, and vegetation and soil cover, vary greatly across the Mediterranean basin (as shown in Chapters 3, 6, 7 , and 8).

One measure of a well-developed karst environment is where the water and material fluxes in sub-surface conduits exceed those in surface channel flows. On the surface, closed depressions may develop above points of drainage input and subterranean cave development and these processes commonly include an element of mechanical failure and material collapse into voids below (Jennings 1985). Thus the characteristic landforms above and below ground that create karst terrains result primarily from the action of dissolution along the ordered pathways provided by bedrock structure (Ford and Williams 1989). Dissolution beneath a soil and vegetation cover, and on bare rock, also produces the etched, pitted, and fretted rock forms (karren) referred to above. Figure 10.4 shows a series of narrow solution channels formed in steeply sloping (almost vertical in places) limestone in the Durmitor National Park of Montenegro where rainfall exceeds 

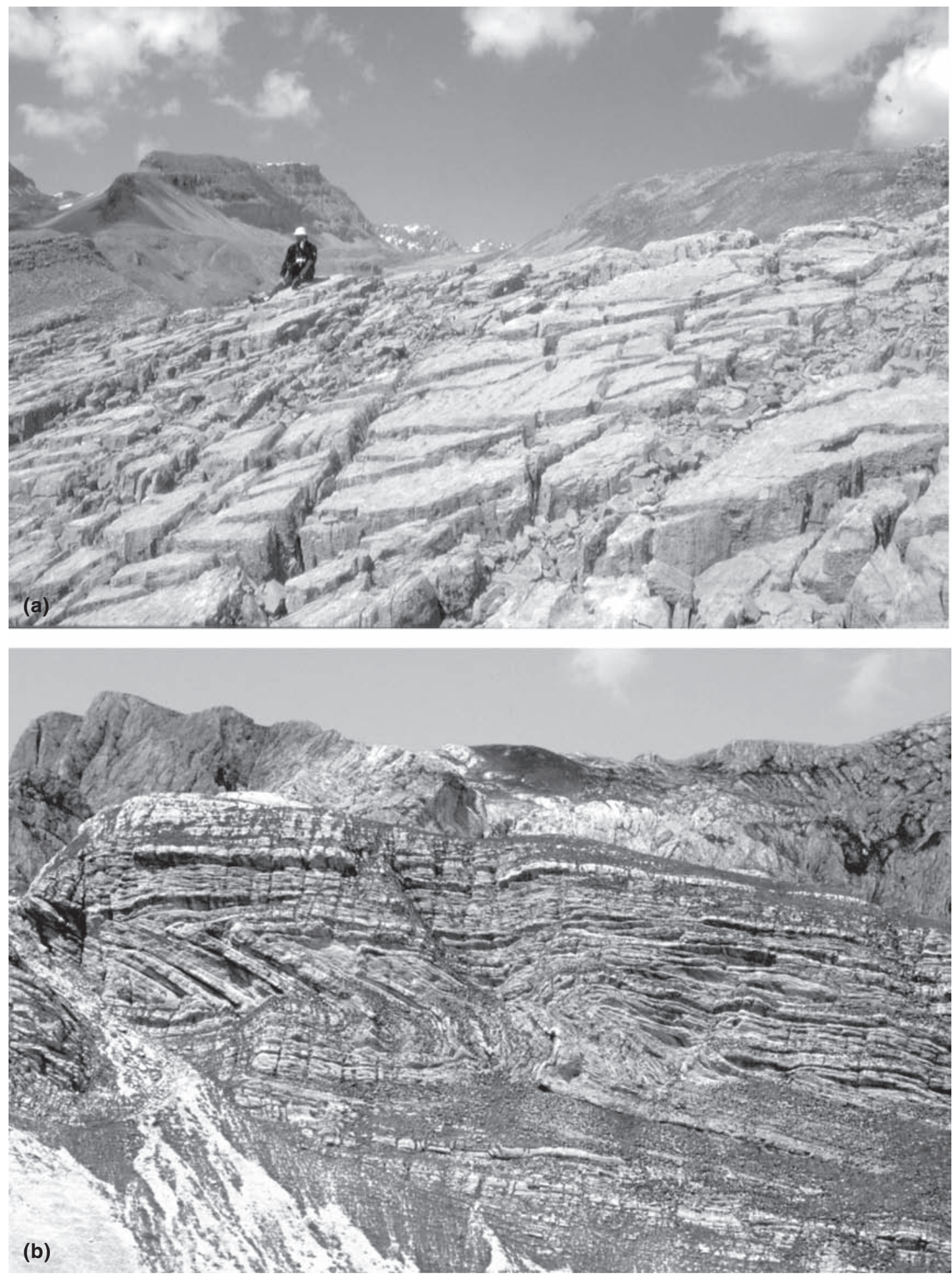

Fig. 10.3. Bedding planes and joints in Mediterranean limestones. (a) Glacially-planed limestone pavement in Eocene limestones on Mount Tymphi in north-west Greece showing well-developed clints and grikes. (b) Tectonically deformed and faulted limestones with well-developed beds and joints exposed in a glaciated valley side in the mountains of Montenegro in the Durmitor National Park (photos: Jamie Woodward). 


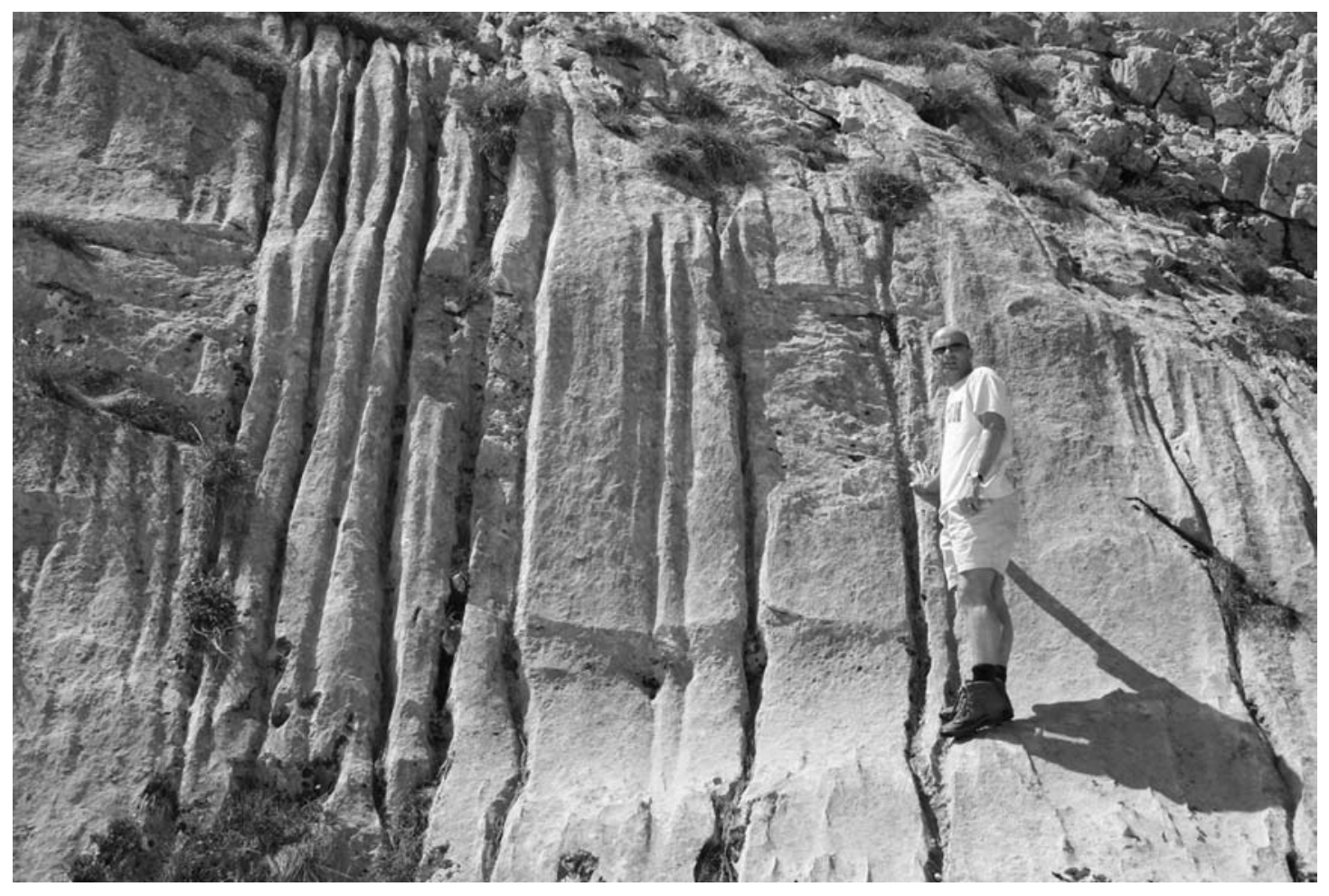

Fig. 10.4. Large-scale solution channels in limestone in a formerly glaciated valley, Durmitor Massif, Montenegro (photo: Philip Hughes). The parallel channels have a mean width of about $12 \mathrm{~cm}$ and are irregularly spaced across the rock face.

3,000 mm per year. Other geomorphological processes can also be important and can operate in close association with solutional activity to breakdown bedrock surfaces. For example, Figure 10.3a shows a welldeveloped limestone pavement formed by glacial erosion where the initial joint spacings have been enlarged by solution weathering to form a regular arrangement of grikes (kluftkarren). Note also the development of smaller-scale solution flutes (rillenkarren) on the surface of the clints (flackkarren), and the important role of frost shattering in rock breakdown in this alpine environment.

Carbonate rocks comprise by weight more than 50 per cent carbonate minerals and there is a continuous range between pure calcite or aragonite and dolomite (Ford and Williams 1989). It should be stressed, however, that not all limestones develop such characteristic surface and sub-surface forms. Some may be mechanically weak with high primary porosity-and this can prevent the development of major underground flow pathways. In Tunisia, for example, despite the abundance of limestones and dolomites, well-developed karst is not widespread and Perritaz (2004) has argued that this may be due to the limited vertical thickness of the carbonate rocks in many cases.

Non-limestone rocks may also develop karstic forms through dissolution: these include evaporites such as halite (rock salt) (Frumkin 1994) and sulphate rocks such as gypsum and anhydrite. These rocks are well developed in various parts of the Mediterranean region as a legacy of the Messinian Salinity Crisis (Chapter 1) and gypsum karsts in particular have been the focus of much research activity (Klimchouk et al. 1996; Calaforra and Pulido-Bosch 2003) (Figure 10.5). In addition, even some silica-cemented sandstones may produce dissolution features comparable to those observable in classical limestones. Quaternary-age cemented limestone gravels can also form striking karst landscapes, as on the Montello plateau in Italy (Ferrarese et al. 1998). Finally, it is worth noting that fluvial landforms on limestones reflect many factors common to other lithologies, as in the case of gorges transecting uplifting fault and fold mountain systems in tectonically active areas. 


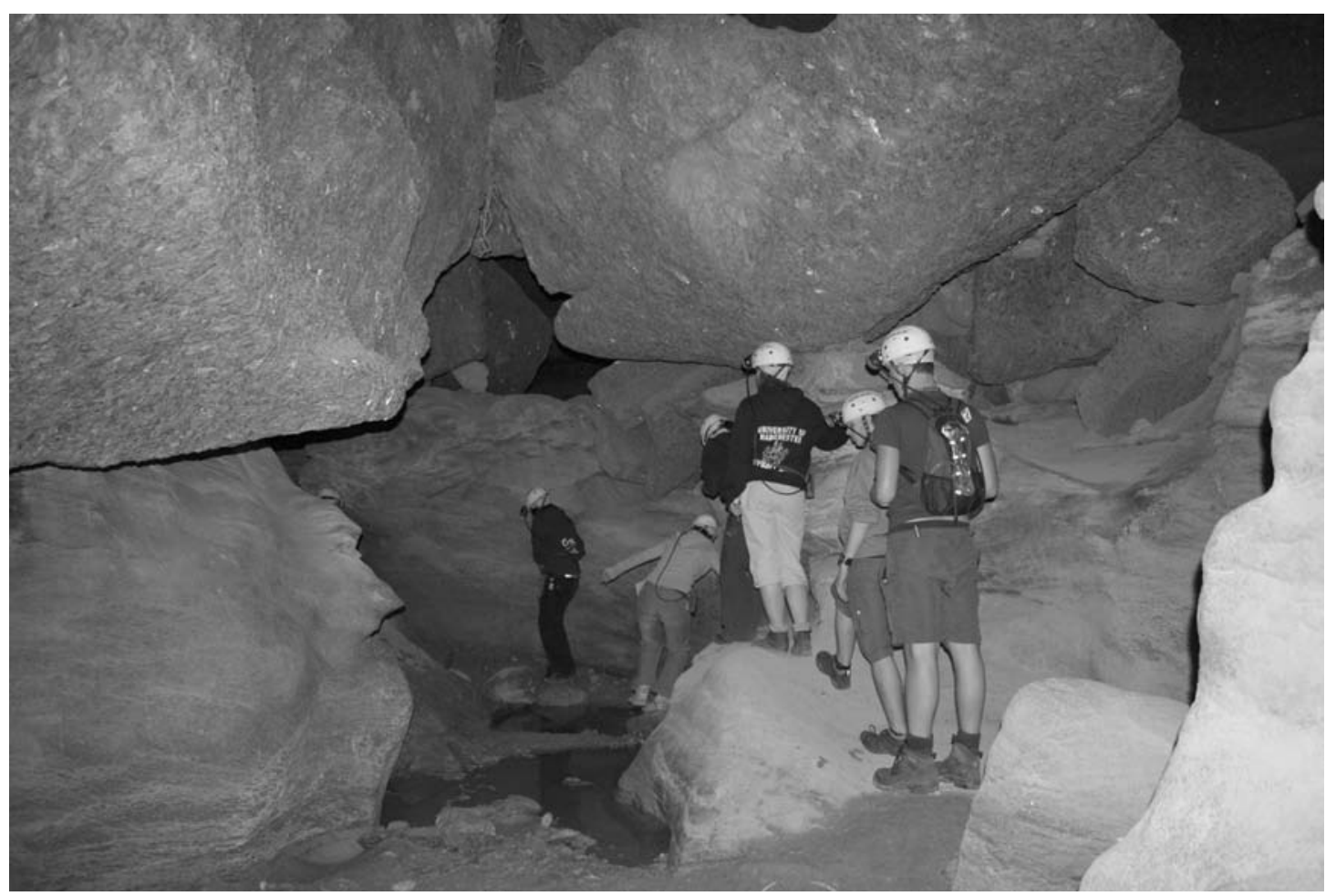

Fig. 10.5. Geography students from the University of Manchester exploring the cave systems in the gypsum of the Sorbas basin in southeast Spain in March 2006 (photo: Jamie Woodward). Here the main cave passages developed following a shift from phreatic to vadose conditions associated with regional base level fall in the Late Quaternary when flowing water excavated the erodible marl sediments that are intercalated with gypsum beds.

\section{The Evolution of Mediterranean Limestones}

Figure 10.1 shows the distribution of carbonate rocks in the Mediterranean region. This involves, for example, a third of France and Turkey, a quarter of Spain, and 40 per cent and more of Croatia and Slovenia. With the exception of the southern and eastern Mediterranean (Libya, Egypt, and the Levant), mechanically resistant limestones commonly form high relief elements in the landscape (Figure 10.3), with eroded weaker materials removed from around them, and fault-bounded margins with deeply entrenched valleys combining to make limestone massifs a dominant landscape element in the region. At the macro-scale this can be explained in terms of geological history and tectonic evolution (Chapter 1). These limestones-including shallow lagoonal, reef, and deeper ocean facies-were formed around the open Tethys Ocean that has now been eliminated by plate movements. Interaction of the
African and Eurasian plates (involving also a series of microplates) led to the development of Alpine mountain systems in Cretaceous, Palaeogene, and Neogene times, and thus widespread folding, faulting, and uplifting of the Jurassic and later oceanic carbonate sediments (Figure 10.6). Tectonics involved early folding in the eastern Mediterranean in the Pontides and Hellenides (approximately where Turkey and Greece are now), with Palaeogene activity in the Alps and northern Spain (including the Pyrenees in particular), and Neogene activity spreading to the Betic cordillera of southern Spain and North Africa. This aspect of the evolution of the Mediterranean landscape is presented in more detail in Chapter 1.

Tectonic activity continues today, especially in the north-eastern sector of the Mediterranean with subduction south of Crete and transform faulting active south of Turkey. All this led to extreme deformation in alpine areas, including the incorporation of eroded continental basement rocks in the evolving deformation zones 


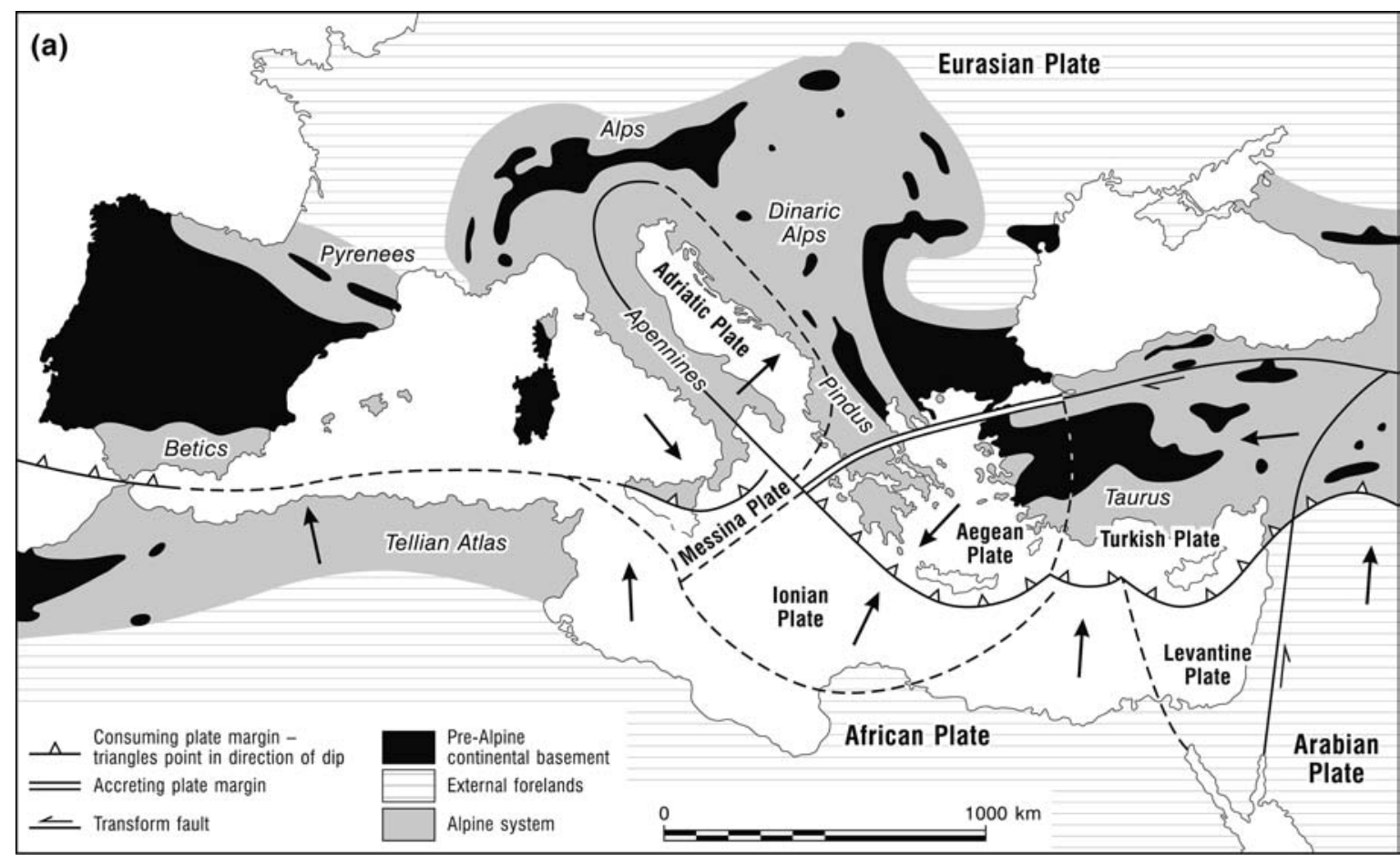

(b)

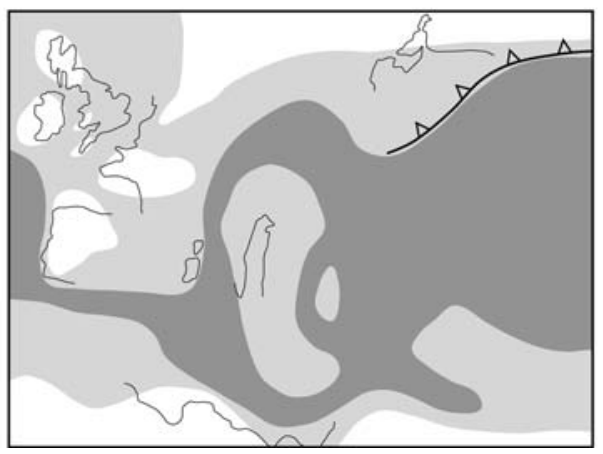

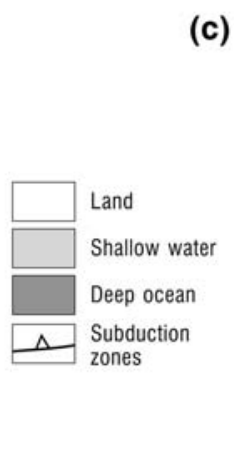

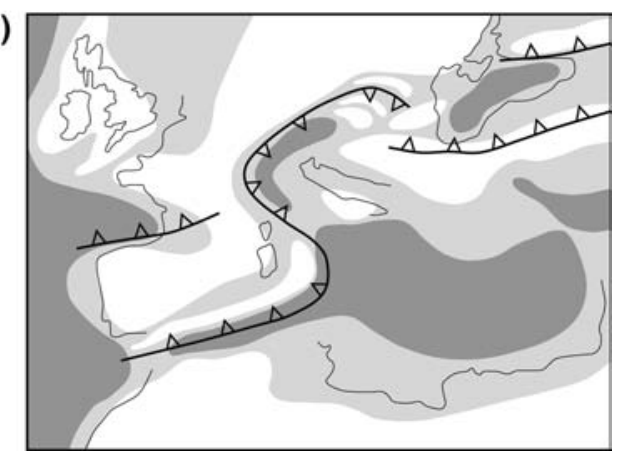

Fig. 10.6. The tectonic setting for the deposition and deformation of Mediterranean limestones. (a) The present-day tectonic setting of the Mediterranean region (modified from Dewey et al. 1973; and Windley 1984; and see Chapter 1). Most of the limestone terrains shown on Figure 10.1 lie within the Alpine system. The evolution of the Tethyan Ocean and major subduction zones at (b) 200 million years BP and (c) 50 million years BP (modified from Biju-Duval et al. 1977 and King et al. 1997).

(Figure 10.6) and the formation of recumbent folds and thrusts. This activity has broadly led to the juxtaposition of rock types that can be highly contrasted physically and chemically, for example with fault-defined limestone massifs dominating the appearance of landscape and coastline on a large scale and later erosion products (e.g. flysch sediments) being removed preferentially around them (e.g. Woodward 1995; Bailey et al. 1997; King et al. 1997). Upstanding limestone blocks can form dra- matic landscape features as in the case of the Rock of Gibraltar, with its peak at $426 \mathrm{~m}$, that lies at the western end of the Mediterranean Sea (Figure 10.1). This is a block of Jurassic limestones and dolomites that has been inverted by earth movements.

In the southern and eastern Mediterranean, marine onlap in Jurassic and later times (van Houten 1980) was succeeded by marine regression and the deposition of terrestrial sediments-but without the intense 
tectonic deformation involved in Alpine mountain building that characterized much of the northern Mediterranean regions. The result has been the development of a fringe of largely undeformed limestone around the southern and eastern Mediterranean (Figure 10.1) which is different in appearance and character to those described above. Thus there are extensive and almost horizontal (low-elevation) limestone plateaus in Libya and Egypt, with deeper valleys and a more dissected landscape in the hills and mountains in the Levant. Tectonic processes have, however, been rather more active in the Levant-along the Jordan transform fault and in the mountainous Lebanon, for example, where elevations may exceed 3,000 m. By contrast, elevations on the limestone plateaus in Egypt and Libya are generally below $1000 \mathrm{~m}$, with extreme aridity resulting in their partial coverage by sand seas (Waltham 2001, and see Chapter 14). These factors combine to produce a very different geomorphological setting for these karst landscapes in comparison to those in the northern and western Mediterranean.

Other limestone terrains which have a somewhat lower degree of deformation and sometimes local relief also exist where they formed in continental basements or ocean floors which have been little transformed. These include parts of eastern Spain, the Grand Causses in France (with upland plateaus dissected by 500-m deep valleys), and the Apulian coast in Italy. Parts of the Apulia platform have preserved a relatively undisturbed (>5,000 m) sequence of Mesozoic limestones as the host microplate became sandwiched between the closing African and European continents (Ager 1980). The Gargano Peninsular (Figure 10.1) has the greatest development of karst features in Italy (Herak and Stringfield 1972: 103).

Whilst most Mediterranean limestones are Mesozoic and Cenozoic (Jurassic and later) in age, there are some areas of Palaeozoic limestones that can give rise to notable karst landscapes. For example, Carboniferous limestones in the Picos de Europa form high mountains (rising to 2,426 m) with karst features rivaling any in Europe (Smart 1986; Gale and Hoare 1997) (Figure 10.1 and Chapter 12).

\section{Mediterranean Karst Systems}

General features involved in evolving karst systems are encapsulated in Figures 10.7 and 10.8. These are based on Ford and Williams (1989) and Gillieson (1996) and the reader is referred to these and other general or specific texts for a comprehensive coverage of karst geomorphology, hydrology, and geochemistry (see also Jakucs 1977; Jennings 1985; White 1988; Gunn 2004). Such features characteristically develop on limestone terrains in humid or seasonally humid environments, with sub-surface drainage developing between points of influent and effluent flow. This may involve allogenic (derived from outside the limestone area) rivers in blind valleys (with no surface topographic exit) entering a cave system that develops over time as passages are enlarged and adjacent rocks are lowered. Cave systems may develop by gravity water flow in an aerated zone (vadose system) or below a water table (phreatic system) which may involve deep water circulation under pressure (Figure 10.7). The cave systems below the surface reflect this in their morphology, with fissure-related open chambers and canyonlike forms with incising stream beds in the vadose zone, and solution tubes enlarged around their whole perimeter by upward as well as downward flow below. Figure 10.7 illustrates the evolution of a system primarily by phreatic streams, initially involving deep, water-filled (bathyphreatic) tubes, but with the later active water system becoming focused on developments at the water table, leaving the relict passages developed earlier as part of an explorable system. Water re-emerges - via the resurgence-as a major river. Modern research suggests that cave enlargement affects only some pre-solutional openings, especially drawing from diverted influent waters from perched streams, glacial meltwaters, and soluble/insoluble rock contacts (Palmer 1991).

\section{Mediterranean Karst Springs}

Karst groundwaters emerge at the surface as springs. In contrast to springs in porous, non-karstic rocks, karst springs tend to have much higher discharges because sub-surface flow velocities can be high and they represent the output point from an extensive network of groundwater conduits (Smart and Worthington 2004). Table 10.1 lists twenty-nine of the largest karst springs so far identified around the world and more than half of these are from the Mediterranean region. The three largest springs in the region are from Trebišnjica in Herzegovina, Bussento in Italy, and Dumanli in Turkey with mean annual discharges of $80,>76$, and $50 \mathrm{~m}^{3} \mathrm{~s}^{-1}$ respectively. It is important to appreciate that flows from springs can be perennial, seasonal, or intermittent and most Mediterranean systems follow the seasonal rhythm of the rainfall regime. In all aquifer systems, the larger the body of water relative to aquifer flow, the greater the residence time, and the more consistent the spring 

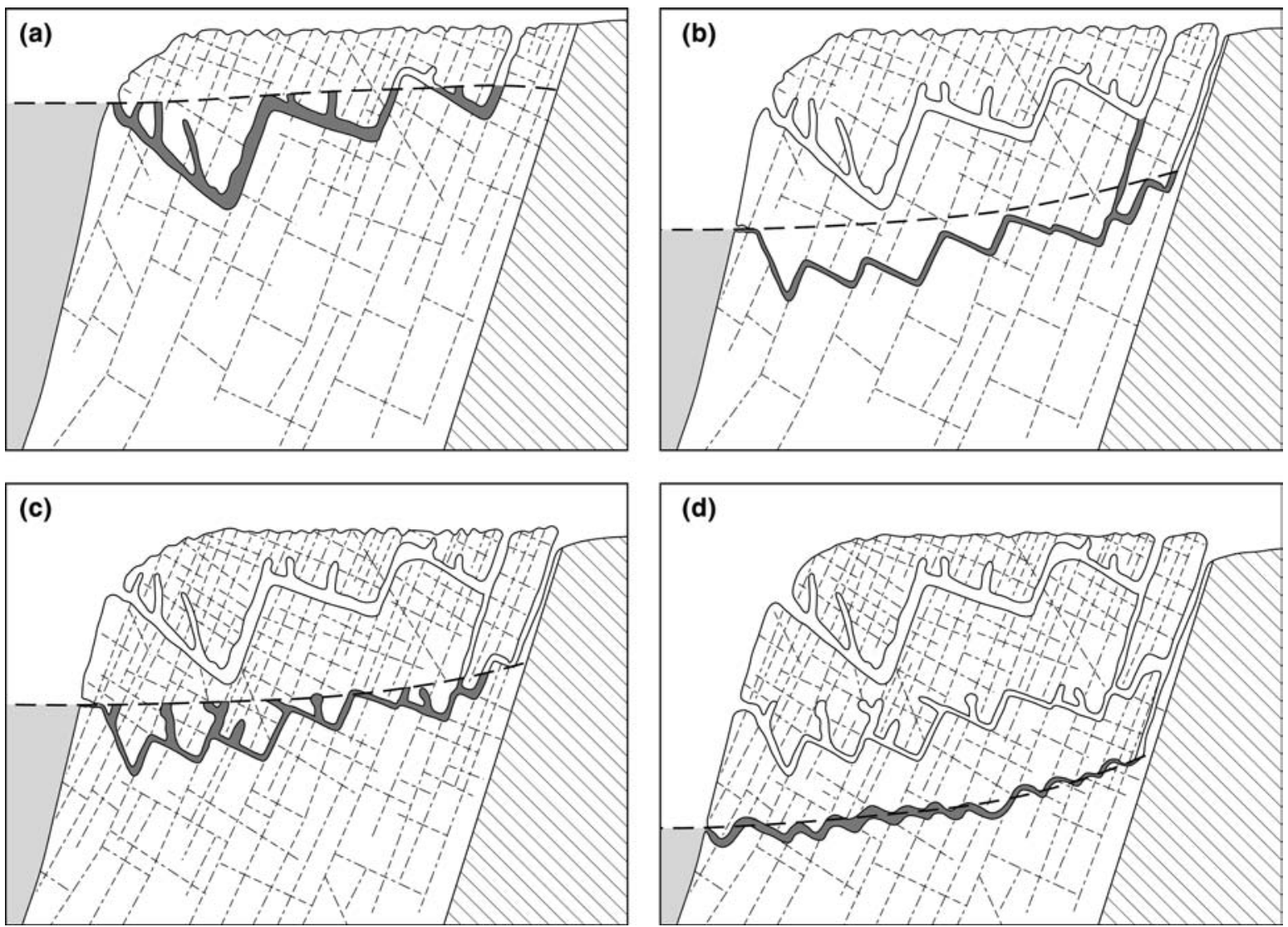

Fig. 10.7. The development of vadose and phreatic cave systems in a karst drainage system. The dashed line marks the level of the water table over time. In general, the main conduits or pipes become enlarged over time and the submerged (phreatic) system in (a) becomes a vadose system in later stages ( $b$ to $d$ ) as the water table falls in accord with external base level change. The karst drainage network develops vertically over time as base level falls. The Mediterranean has some of the deepest karst drainage systems in the world with very long vertical shafts. Some of the deep karsts developed during the Messinian Salinity Crisis (Chapter 1). Note how the number of penetrated fissures in the karst rock increases over time (modified from Ford and Williams 1989). See text for further explanation and compare to Figure 10.8 .

discharge (ibid.). Springs that rise from depth because of the internal hydraulic head in the aquifer, are termed Vauclusian springs after the Fontaine de Vaucluse in southern France which has a mean discharge of $c .21 \mathrm{~m}^{3} \mathrm{~s}^{-1}$ (ibid.).

In upland Mediterranean karsts, the recharge area can be snow-covered throughout the winter and spring, resulting in a significant lag before the snowmelt component enters the karst aquifer. In the deep limestone karst system of Mount Tymphi in north-west Greece, for example, the amount of snowfall is an important control on the magnitude of summer flows in the Voidomatis River which is fed by a large exurgence in the Vikos Gorge almost 2,000 $\mathrm{m}$ below the highest peaks (Bailey et al. 1997) (Chapter 11).
The widespread occurrence and thickness of carbonate rocks in the Mediterranean region means that the karst system is a key influence upon river flows and water quality.

High-intensity precipitation and snowmelt events can overload the karst system and produce surface flooding. Bonacci et al. (2006) describe a flash flood event in the Dinaric karst of Marina Bay on the central coast of Croatia. During extreme events, groundwater levels in parts of the Dinaric karst can rise at a rate of $>30 \mathrm{~m}$ per hour and this can lead to rapid groundwater breakthrough, often under pressure, in many unexpected locations. On 6 December 2004 a precipitation event, with an estimated return period of between 800 and 1,000 years, fell on the area producing a 


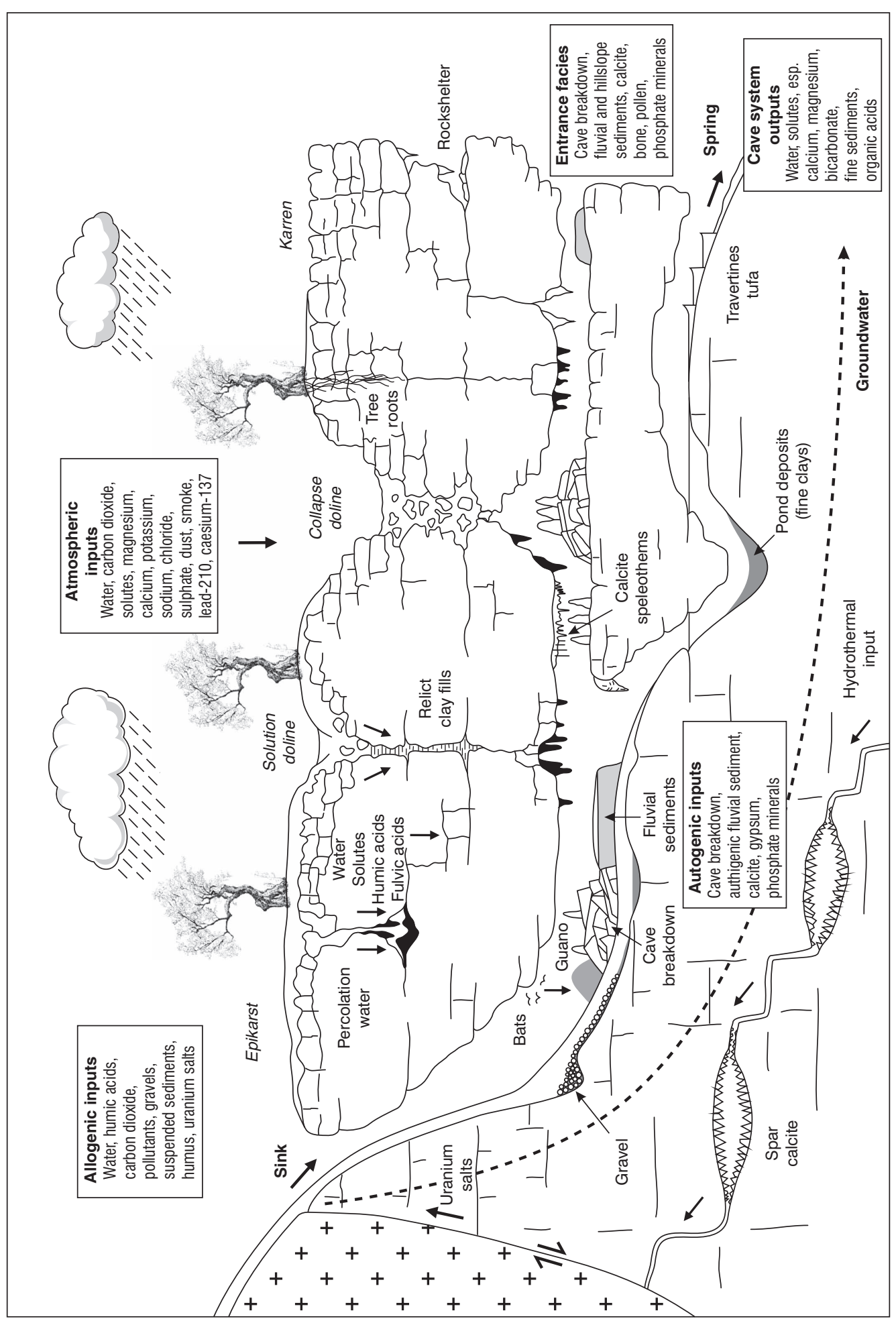

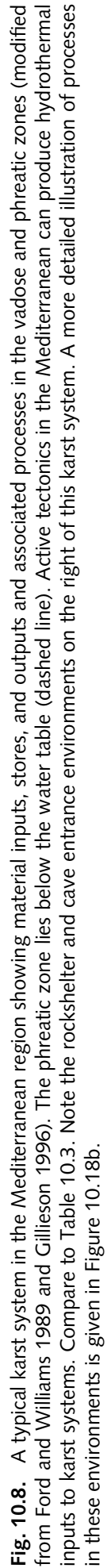


TABLE 10.1. Large discharge springs of the world with flows $>20 \mathrm{~m}^{3} \mathrm{~s}^{-1}$

\begin{tabular}{|c|c|c|}
\hline Spring & $\begin{array}{l}\text { Discharge } \\
\left(\mathrm{m}^{3} \mathrm{~s}^{-1}\right)\end{array}$ & $\begin{array}{c}\text { Catchment area } \\
\qquad\left(\mathrm{km}^{2}\right)\end{array}$ \\
\hline Tobio, Papua New Guinea & $>100$ & - \\
\hline Matali, Papua New Guinea & 90 & 350 \\
\hline Trebišnjica, Herzegovina & 80 & 1,140 \\
\hline Bussento, Italy & $>76$ & - \\
\hline Dumanli, Turkey & 50 & 2,800 \\
\hline Galowe, Papua New Guinea & 40 & - \\
\hline Ras el ain, Syria & 39 & - \\
\hline Tisu, China & 38 & 1,000 \\
\hline Ljubljanica, Slovenia & 39 & 1,100 \\
\hline Stella, Italy & 34 & - \\
\hline Ombla, Croatia & 34 & 600 \\
\hline Chingshui, China & 33 & 1,000 \\
\hline Spring Creek, Florida & 33 & $>1,500$ \\
\hline Oluk Köprü, Turkey & $>30$ & $>1,000$ \\
\hline Timavo, Italy & 30 & $>1,000$ \\
\hline Frio, Mexico & 28 & $>1,000$ \\
\hline Yedi Miyarlar, Turkey & $>25$ & $>1,000$ \\
\hline Mchishta, Georgia & 25 & - \\
\hline Buna, Herzegovina & 24 & 110 \\
\hline Coy, Mexico & 24 & $>1,000$ \\
\hline Liu longdong, China & 24 & - \\
\hline Kirkgozler, Turkey & 24 & - \\
\hline Silver, Florida & 23 & 1,900 \\
\hline Rainbow, Florida & 22 & $>1,500$ \\
\hline Vaucluse, France & 21 & 1,100 \\
\hline Sinjac (Piva), Montenegro & 21 & 500 \\
\hline Bunica, Herzegovina & 20 & 510 \\
\hline Grab-Ruda, Croatia & 20 & 390 \\
\hline Trollosen, Spitzbergen & 20 & - \\
\hline
\end{tabular}

Note: More than half of these are from karst systems in the Mediterranean region.

Source: Modified from Ford and Williams (1989) and Milanović (2000).

large number of new high discharge springs. Many house cellars were flooded by the rapidly rising groundwater and the main street in Marina was flooded by an open watercourse to a depth of $0.5 \mathrm{~m}$. Such an event had never been recorded previously and it caused damage estimated at US\$1.5 million (ibid.). Jourde et al. (2007) have demonstrated the importance of contributions from the karst groundwater system to flood flows in the Coulazon River near Montpellier in southern France.

\section{Mediterranean Cave Systems}

Figure 10.8 shows a mature cave system in a karst landscape and the text boxes show the inputs, storages, and outputs of materials and some of the processes involved. Reworked soils such as terra rossa are a common input to Mediterranean karst cave systems and the root systems of olive trees commonly exploit the cavities in the upper part of the bedrock surface.

A range of surface limestone features (epikarst, dolines, and karren), and the transformations that are likely to occur as cave systems become abandoned by flowing water are also shown in Figure 10.8. These include speleothem formation (Figure 10.9a) and the partial blocking of conduits by fine clastic sediments. These sediments are often derived from non-limestone source rocks such as flysch and sandstones and they can exit the karst system via flowing water (Figure 10.10). Chemical and physical sedimentation of this kind within the karst system can permit the development of an environmental record (including the preservation of a human occupation history in cave mouth and rockshelter settings) which is not available in other eroding landscapes. The environmental records from speleothems are discussed in more detail below. Large passages in mature karst systems can transmit large flows during floods and the flux and storage of well-rounded gravels can be an important part of the clastic sediment budget. Angular, coarse-grained sediments may be introduced via dolines and roof collapse and they can accumulate in rockshelter and cave-mouth environments where physical weathering of the bedrock walls and ceiling take place.

Outside the subterranean karst environment, precipitated and cemented carbonates including travertines and tufas (Figure 10.9b) may preserve a valuable and datable environmental record that is also not available for other lithological environments (Pena et al. 2000; Glover and Robertson 2003).

More recent research has also revealed the abundance of limestone cave and cavern systems in the Mediterranean region, with exploration demonstrating their extreme depth dimension in many cases. Herak and Stringfield (1972) usefully catalogue the cave systems of France, Italy, and the former Yugoslavia, though the picture changes as exploration unfolds. Klimchouk (2004) has recently compiled a list of the deepest caves in the world and, as he points out, many are located in the young mountain belt that extends across Europe from the Pyrenees to the Caucasus. Many are located within the thick carbonate rocks of the countries that border the Mediterranean Sea including the Réseau JeanBernard (depth 1,602 m) in Haute-Savoie, France, and the Torca del Cerro (depth 1,589 m) in the Central Massif of the Picos de Europa of Spain. Table 10.2 lists some world comparisons to provide global context for the Mediterranean examples. The Picos contains the largest-known concentration of deep caves in the world (Rossi 2004) with at least fifteen caves more than $900 \mathrm{~m}$ 

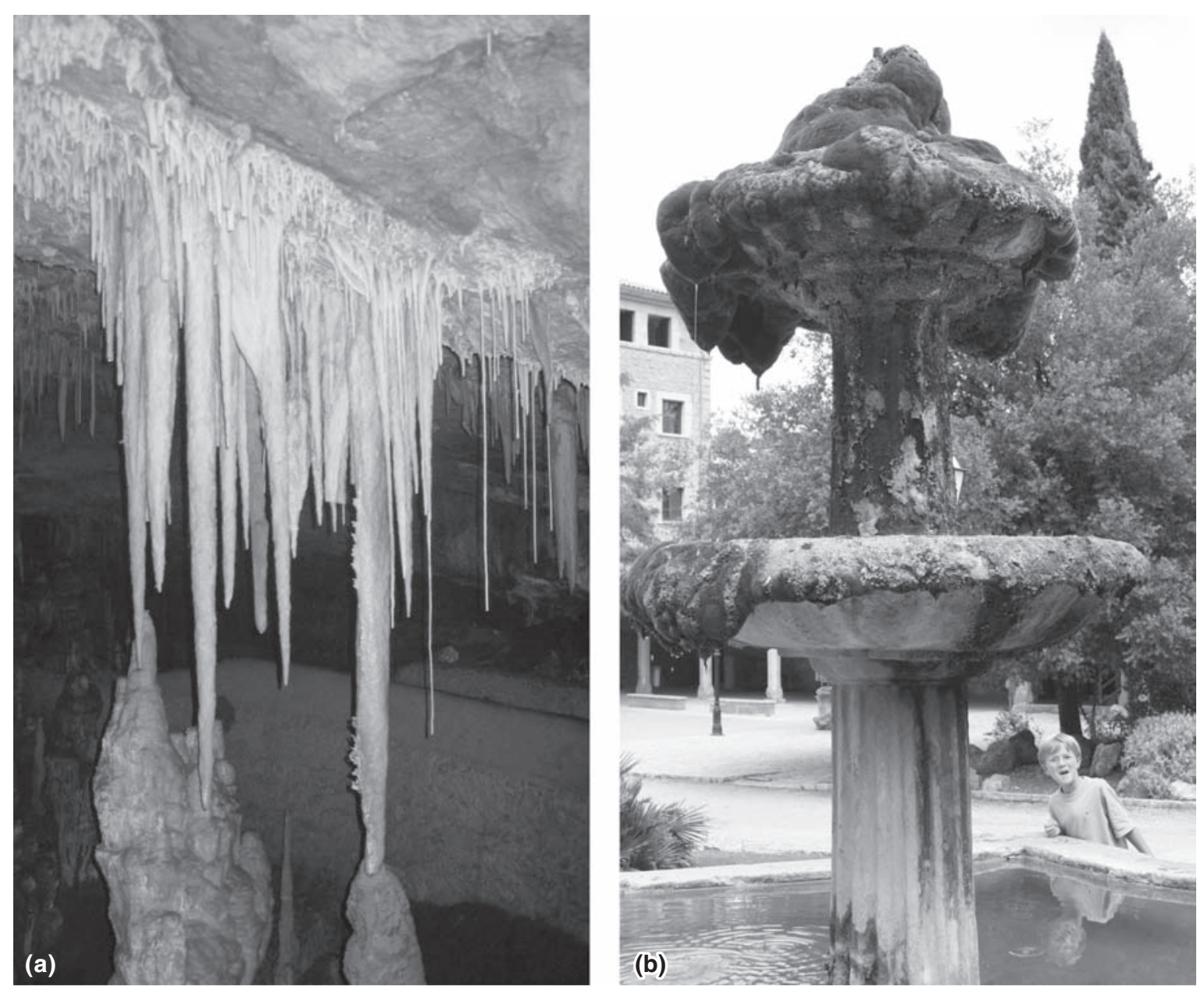

Fig. 10.9. Features produced by the precipitation of calcium carbonate in karst environments in Majorca, Spain. (a) Speleothems from Campanet Cave and (b) tufa deposition on a fountain in the grounds of the monastery at Luc (photos: Jamie Woodward).

deep. Many consist of fault-guided shafts interconnected by narrow canyons. The Picos were glaciated on numerous occasions during the Pleistocene and there is evidence of a large $\left(c .50 \mathrm{~km}^{2}\right)$ ice cap on the western Massif. Here many of the large vadose caves may be partially sub-glacial in origin (Rossi 2004) and Smart (1986) has pointed out that many large shafts probably owe their formation to large influxes of meltwater since they are located in areas that receive little modern drainage.

A key feature of Mediterranean karsts is their extensive vertical development and this is due to the region's distinctive geological and geomorphological history. Many karst aquifers across the northern part of the region therefore contain multiple levels of passages and these are often joined by very deep vertical shafts (e.g. Waltham 1978; Courbon and Chabert 1986). In fact, Mediterranean karsts contain some of the deepest vertical shafts so far identified and, as far as water flows are concerned, this can result in sub-surface drainage systems with highly unusual three-dimensional configurations that are uncommon or impossible in surface catchments (Smart and Worthington 2004). Bakalowicz et al. (2008) have conducted hydrogeological assessments of deep karst systems in Lebanon. They represent very significant water resources - the Zarka system, for example, which is the source of the Orontes River, has a storage capacity of 27 billion $\mathrm{m}^{3}$. 


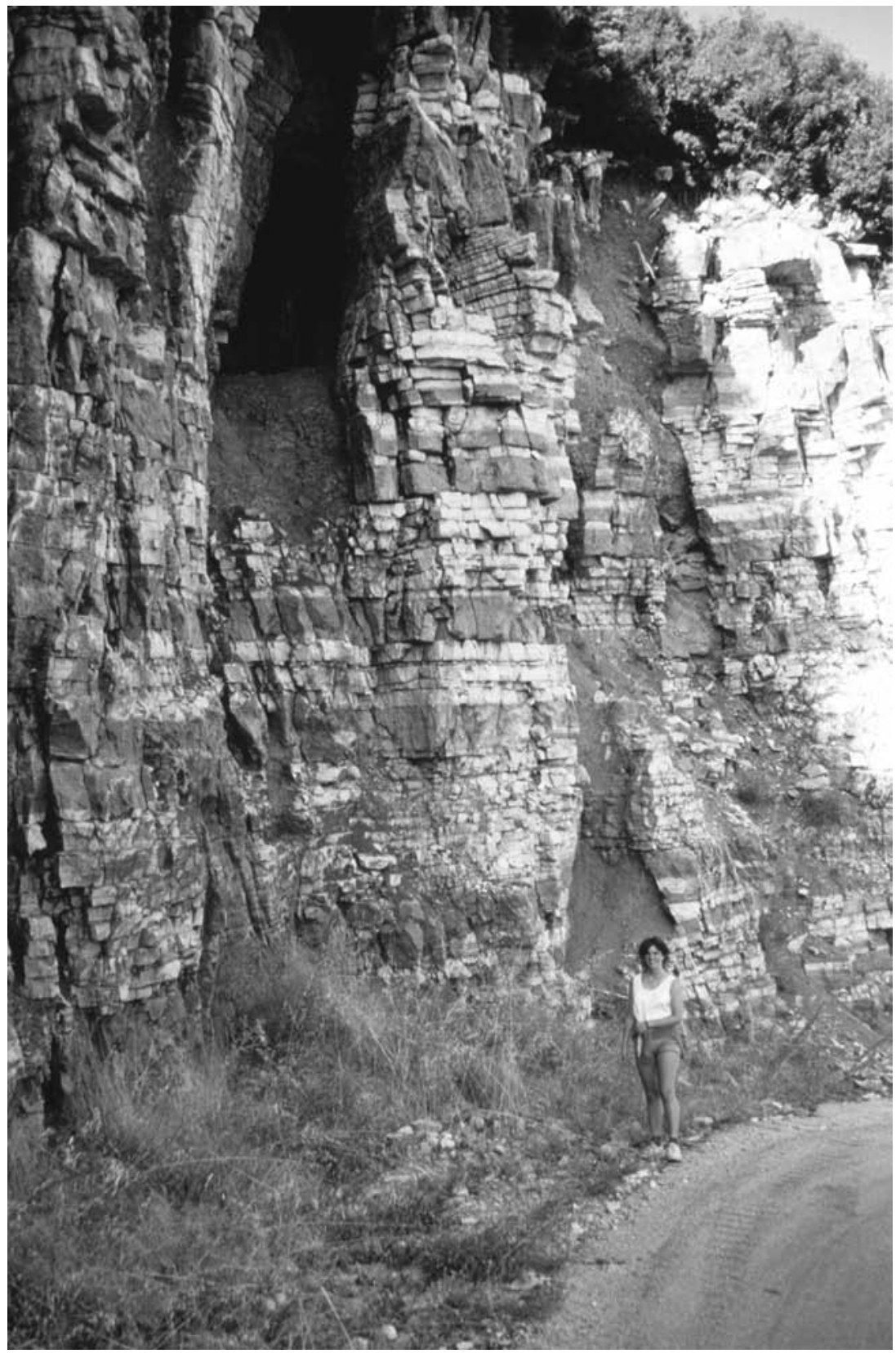

Fig. 10.10. Fine-grained sediment outputs from a Mediterranean karst system. The large conduits are formed in Late Eocene limestones in the Lower Vikos Gorge of the Voidomatis River basin. The fine sediments are derived from flysch rocks and soils that overlie the limestones and they represent an important part of the clastic sediment budget in the subterranean karst system (see Figure 10.8 and Woodward 1997) (photo: Jamie Woodward).

\section{Mediterranean Karst Landscapes}

Figure 10.11, based on Jakuc (1977), suggests an altitudinal range in processes and four main landscape elements (A to D); from alpine karst (with glaciers and bare limestone karst present above around 3,000 m) through zones of increasing karstification and the development of surface forms and weathering residues at lower elevations. Glaciers are present in the region today in the highest mountains and were much more extensive during cold stages of the Pleistocene (Chapter 12). Jakuc's model envisages a deep (vadose) cave system 
TABLE 10.2. The twenty deepest caves in the world

\begin{tabular}{rllc}
\hline Rank & \multicolumn{1}{c}{ Name } & Country & Depth $(\mathrm{m})$ \\
\hline 1 & Gouffre Mirolda & France & 1733 \\
2 & Krubera (Voronja) & Georgia & 1710 \\
3 & Lamprechstofen & Austria & 1632 \\
4 & Réseau Jean-Bernard & France & 1602 \\
5 & Torca del Cerro & Spain & 1589 \\
6 & Cehi 2 "la Vendetta" & Slovenia & 1533 \\
7 & Sarma & Georgia & 1530 \\
8 & Vjacheslava Pantjukhina & Georgia & 1508 \\
9 & Sistema Cheve & Mexico & 1484 \\
10 & Sistema Huautla & Mexico & 1475 \\
11 & Sistema del Trave & Spain & 1441 \\
12 & Boj Bulok & Uzbekistan & 1415 \\
13 & Puertas de Illamina & Spain & 1408 \\
14 & Lukina Jama & Croatia & 1392 \\
15 & Evren Gunay düdeni & Turkey & 1377 \\
16 & Sneznaja-Mezhennogo & Georgia & 1370 \\
17 & Réseau de la Pierre Saint-Martin & France-Spain & 1342 \\
18 & Siebenhengste & Switzerland & 1340 \\
19 & Slovacka jama & Croatia & 1320 \\
20 & Cosa Nostra Loch & Austria & 1291 \\
\hline
\end{tabular}

Note: Most of the caves in this list were explored 'top-down' from an upper entrance or entrances and their depth is defined as the vertical range between the altitude of the highest entrance and lowermost point reached in the cave (see Klimchouk 2004). Some caves extend below the local water table and are waterfilled. This makes exploration difficult and some of the depths are therefore minimum values.

Source: Modified from Klimchouk (2004).

in high relief zones of intermediate elevation, with an enlarged water table cave system below. The model is a useful one that encompasses many of the karst environments encountered in the Mediterranean region. It does not, however, include desert karst environments and this distinctive setting is described more fully in a later section.

The impact of humans on karst environments also varies to some extent with elevation. In many parts of the Mediterranean karst surfaces have been directly modified to enhance their agricultural potential (Gams et al. 1993). Figure 10.12 shows two forms of karst surface modification that are widespread in the Dinaric karst. The left hand diagram ( $1 \mathrm{a}$ and $1 \mathrm{~b}$ ) shows how stone block-fronted terraces can be developed by removing limestone blocks to create a stepped hillslope profile and a deeper soil mantle. The right hand diagram (2a and $2 \mathrm{~b}$ ) shows how a funnel-shaped doline has been modified (again with the movement of both bedrock blocks and soil) to create a larger and flatter area for cultivation. These direct modifications to hillslopes and soils are most common in karst zone D of the Jakuc model (Figure 10.11) and further examples are presented in Gams et al. (1993).
The range in altitude and relief across the Mediterranean is believed to have a very strong effect on karstic processes and landscape development. Parts of Galicia (north-west Spain), the Pyrenees, the Alps, and the southern Adriatic coast receive over $1,500 \mathrm{~mm}$ in the mountains in the form of snowfall and annual precipitation can exceed $4,500 \mathrm{~mm}$ in the mountains of Montenegro. In the mountains, the hydraulic gradients in the karst system are much greater and the fall in elevation between groundwater recharge areas and outlet springs can be $>2,000 \mathrm{~m}$. High precipitation in these areas results in a much greater overall throughput of water and solutes so that karstic processes are much more active than in the low relief dryland karst of the southern Mediterranean where hydraulic gradients are much shallower and water fluxes are much lower. In Libya and Egypt, only very limited parts of the coastal limestone zone around Tripoli and the Jabal al Akhdar uplands receive more than $250 \mathrm{~mm}$ in winter rains (Chapters 3 and 11). While carbonate solubility is, in fact, greater at low temperatures, this effect is almost totally outweighed by the influence of organic acids in soil and vegetation covered areas.

For the reasons discussed above, Mediterranean karst is more varied and more complex to interpret than early work in the karst plateau of Trieste was able to reveal. Even features once taken as 'textbook' karst forms turn out to be more varied. For example, poljes — which are flat-floored depressions up to $400 \mathrm{~km}^{2}$ and more in area-were once regarded as an end stage enlargement of cyclical surface karst development of doline-style phenomena. They are found widely in the Dinaric limestones (Figure 10.13a), but they have a variety of origins involving structural and process causes (Figure 10.13b). Thus, of the forty-two poljes identified by Gams (1978) in the former Yugoslavia, most are of border (eighteen) or structural (nine) type, rather than base level ones developed in simple limestone (one) (Figure 10.13). Many are, in fact, composite features (eighteen) as Ford and Williams (1989) have pointed out.

\section{Mountain Karst Environments}

Many upland limestone areas in the Mediterranean contain deep valleys formed by glacial action and spectacular gorges produced by fluvial incision as in the Italian Alps, the Pyrenees, the Pindus Mountains, and the Taurus Mountains of Turkey (Chapter 1). Figure 10.14 shows two deep gorges in limestone on the Balkan Peninsula. In some reaches, the Moracha River gorge is extremely narrow-with no long-term fluvial or 


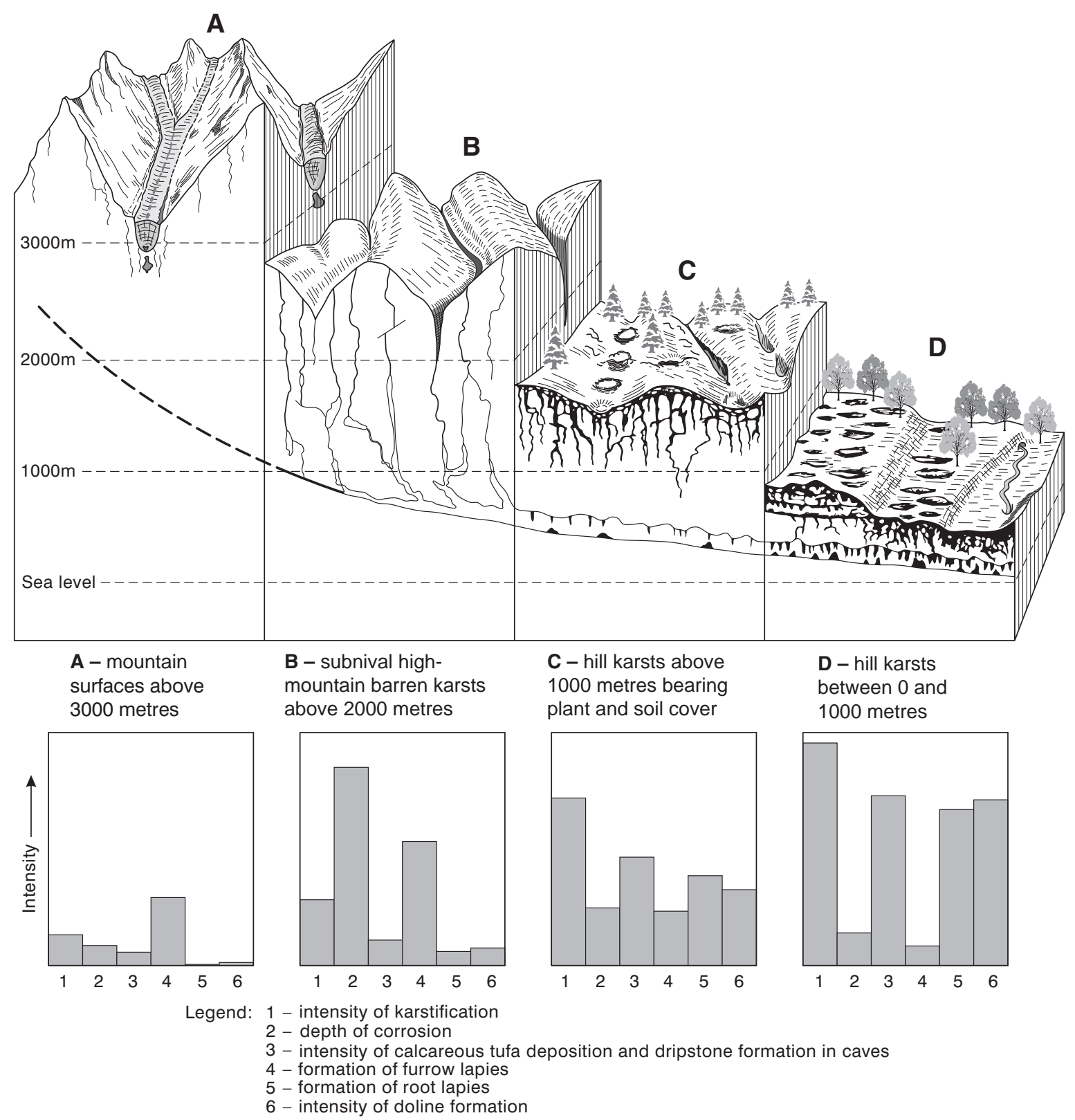

Fig. 10.11. The vertical zonation of karst landscapes and processes in 'European folded mountain regions' modified from Jakucs (1977). The histograms show the intensity of a range of karst processes in the four main landscape elements.

colluvial sediment storage. The steep active channel zone occupies the valley floor and the dominant longterm process here appears to be vertical incision driven by uplift with the hard limestone bedrock resisting lateral erosion of the gorge walls. In contrast, the Vikos
Gorge example represents a more advanced stage of gorge development. This gorge system is much wider and colluvial processes have attacked the gorge walls to produce the thick talus deposits. The valley floor is also much wider with storage space for fluvial sediments of 

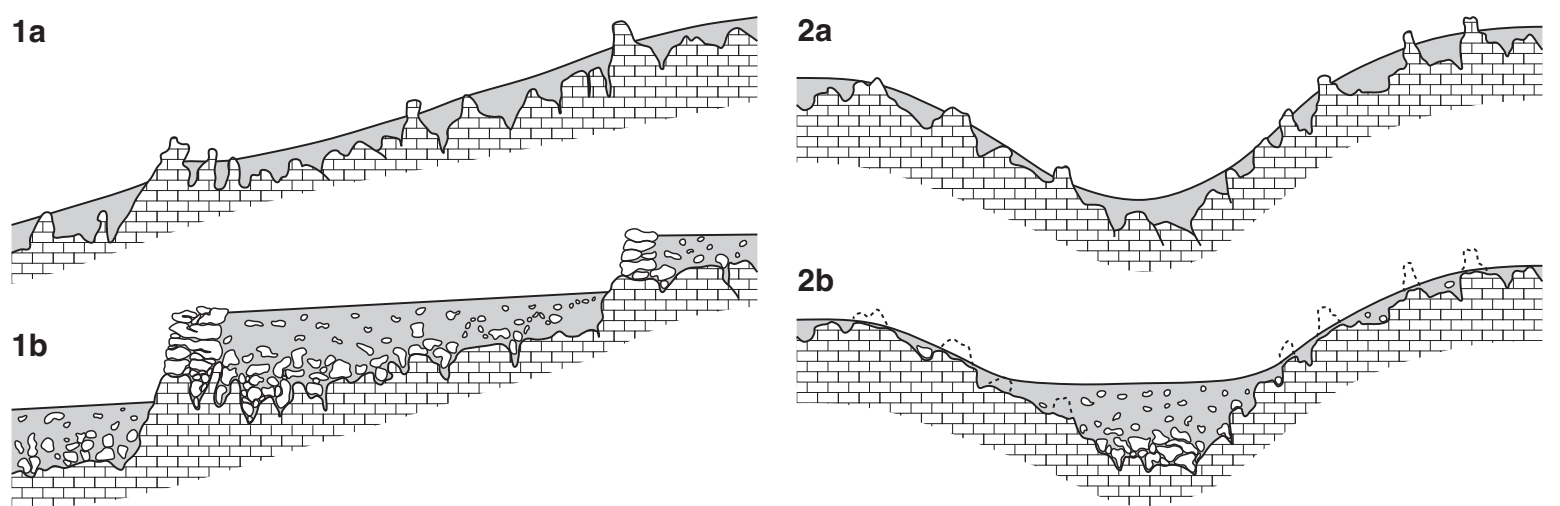

Fig. 10.12. Two forms of intentional human modification to hillslopes in karst environments in the Dinaric region to create deeper soils and a flat surface suitable for cultivation (after Gams et al. 1993). 1a and 1b show the creation of flat agricultural land with stone-walled terrace fronts built from the removal of large blocks of limestone from the original hillslope. $2 a$ and $2 b$ show the creation of a surface suitable for cultivation following the infilling of a funnel-shaped doline with soil and the removal of small-scale limestone pinnacles.

Pleistocene and Holocene age (Woodward et al. 2008). The coarse-grained screes also transmit groundwater flows and cementation by karstic processes is widespread (Bailey et al. 1997).

Many surface karstic features are most clearly seen in high plateau areas where they can be usefully mapped using remotely sensed imagery (Woodward et al. 2004). Alpine karst, in places involving interaction between direct Pleistocene glaciation and karstification (with tillfilled dolines and glacially scoured bedrock pavements, for example) has been explored in the Picos de Europa, Spain (Smart 1986), the Dolomites of Italy (Ferrarese et al. 1998), the High Atlas of Morocco (Perritaz and Monbaron 1998) and the Pindus Mountains of northwest Greece (Woodward et al. 2004) (Figure 10.3a). These areas are all over 2,000 m in elevation (and snow covered for many months of the year) and are subjected to physical and chemical weathering of limestones with karst features developed upon thick limestone sequences. This bare 'high and cold karst' (with surface valleys, dolines, and smaller-scale karren features) dominates the headwater basins of many Mediterranean river systems and provides a marked contrast to the regolith-covered karst of lower altitudes (Figure 10.11). The glaciated mountains of the Mediterranean contain extensive and very wellpreserved limestone pavements (Figure 10.3a). Some of these have been shown to be Middle Pleistocene in age and they have been subjected to several cycles of cold climate thermal shattering and active karst development during warmer climates (Hughes et al. 2006).
Recent work in the Pindus Mountains of north-west Greece has used uranium-series dating to establish the age of secondary calcites that have formed within the coarse-grained glacial sediment (till) matrix (Woodward et al. 2004). Detailed geomorphological mapping and formal lithostratigraphic assessment of the glacial sediments and landforms in the Pindus Mountains has led to the recent development of a new chronostratigraphic model for Pleistocene glacial activity in the Mediterranean region (Woodward et al. 2004, Hughes et al. 2006). Modern glacier dynamics and the Pleistocene glacial record in the limestone uplands of the Mediterranean are discussed more fully in Chapter 12.

\section{The Desert Karst}

Jennings (1985) has argued that hot desert environments are not conducive to karst development because of the low rainfall inputs, very limited vegetation cover and therefore low soil carbon dioxide levels and high rates of evaporation. The presently 'arid karst' of North Africa is beginning to be explored (Albritton et al. 1990; Smith et al. 2000; Waltham 2001). Here the interaction is between limited present-day active development of arid micro-karstic features, active warm desert processes (especially thermal shattering, aeolian activity, and etching and scouring of limestone surfaces by sand blasting and burial of karst forms under mobile sand sheets) (Chapter 14), and what appear to be much more intensive karstic processes under former (wetter) climatic conditions (such as the early Holocene pluvial) and lower sea levels. Thus, sinkholes and caves are present along 

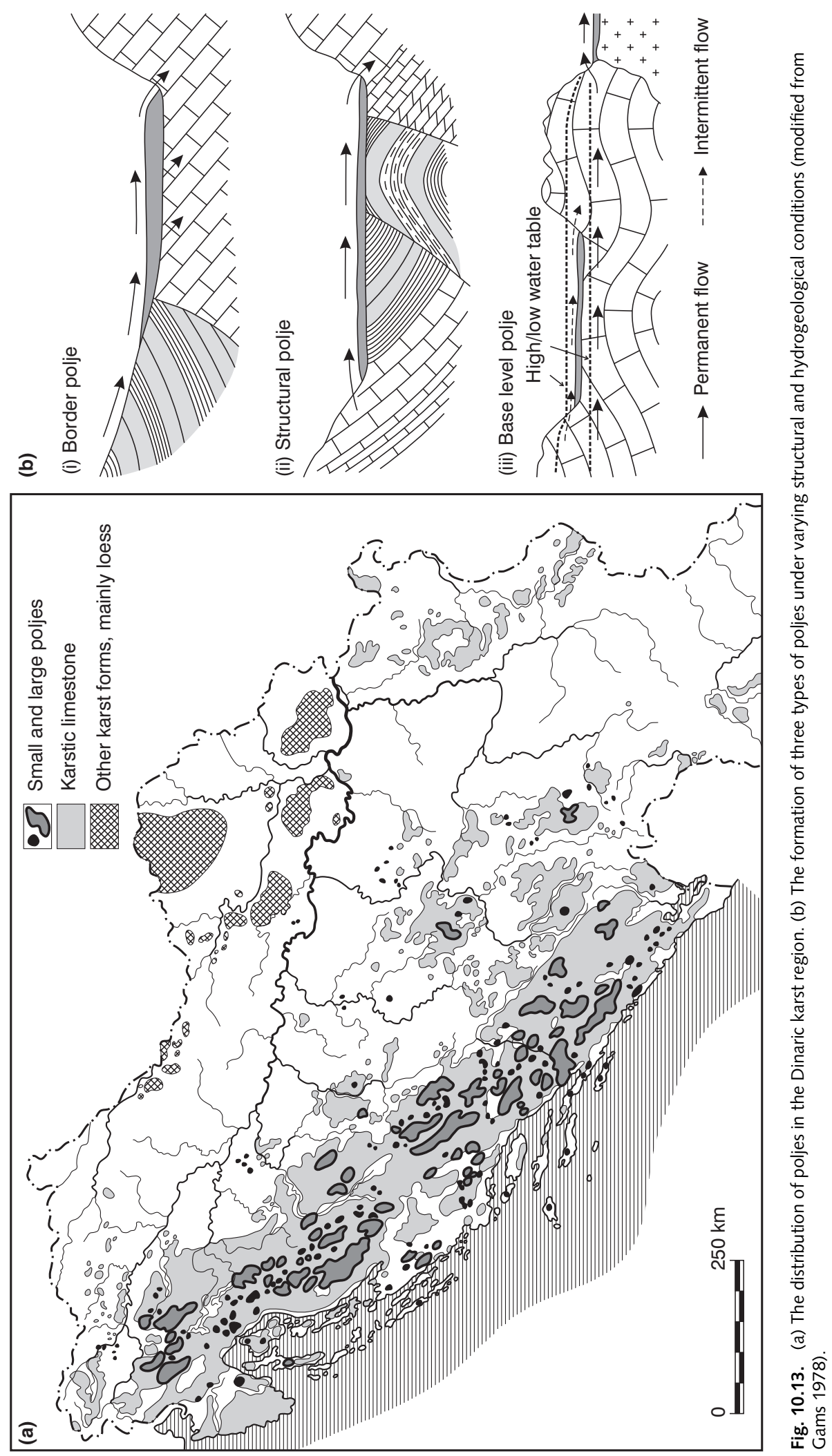
the limestone plateaus of the Egyptian and Libyan desert (Gale et al. 1993), with curious features such as white chalk pinnacles (mostly 2-4 m high) emergent from a cover of orange sand, which are believed to be karst products (Waltham 2001) (Figure 10.15). Thousands of these pinnacles are present in the White Desert of the Farafra Oasis and small areas of karst towers (10-15 m high) are also found. Their origin is uncertain, but Perritaz (2004) has argued that these are relict karst features that formed under wetter climates in the Late Tertiary. Gypsum karst is well developed in Libya and extensive cave systems have been mapped. The Umm al Masabih Cave is $3,593 \mathrm{~m}$ long and it conveys ephemeral stream flows and sediments following desert flash floods (Perritaz 2004).

Limited understanding of these desert karst systems means that it is often difficult to recognize the extent to which karstic features are inherited from previous climatic regimes (relict forms or palaeokarst) during wetter phases of the Quaternary or during the Late Tertiary. The extensive Qatarra depression (about $300 \times$ $145 \mathrm{~km}$ ) (Figure 10.1) may be a former river valley, subsequently dismembered by Late Miocene (Messinian) karstic processes and deepened by deflation. It is difficult to establish reliable geochronologies for many relict karst landscapes in the present arid zone because the secondary carbonates commonly lie beyond the range of uranium series dating.

Karstic features are also developed at the coast of North Africa down to130-150 m below sea level. The Jabal al Akhdar in eastern Libya (Figure 10.1) is a large karst area with large sinkholes and cave systems that discharge into the Mediterranean Sea. Many of these features were first recorded during the Roman Period. Clearly there is scope for research on possibly distinctive systems, perhaps with some analogy to be made to the karst of the Nullabor Plain in Australia, a 'dryland' karst with dolines and a modest density of caves, but an absence of sinks and poljes (Jennings 1985). Speleothems are also poorly developed in this environment (Lowry and Jennings 1974). Similarly, we need more information on the processes and products of chemical weathering of karst surfaces in dryland environments. Under strong evaporation the formation of crusts and precipitates (e.g. calcretes) may have a significant impact on the development of karstic features.

\section{Tufas and Travertines}

An area of strong recent interest concerns tufa and travertine deposits, which are carbonates precipitated from solute-charged karstic waters (Pentecost 1995; Ford and Pedley 1996; Glover and Robertson 2003). Many authors use the term 'tufa' for cool-water carbonates and travertine for hot $\left(>20^{\circ} \mathrm{C}\right)$ spring deposits (see Glover and Robertson 2003). Both types are common in the Mediterranean region reflecting the widespread presence of carbonate host rocks with welldeveloped karstic drainage-and the particular circumstances where active tectonic settings allow such groundwaters to be heated by geothermal energy. The Mediterranean region contains some of the best-known examples of Pliocene and Quaternary age and modern tufa deposits because the physical geography of many localities in the region yields optimum conditions for tufa formation (Figure 10.16). These processes take place at a range of scales. Large tufas may form in tectonically controlled depositional settings that allow extended periods of tufa deposition (Glover and Robertson 2003). These may incorporate many facies types with rich fossil assemblages and, because they can be dated by uranium-series methods, they may represent very significant archives of environmental change.

The coastal city of Antalya and its hinterland in south-east Turkey (Figure 10.1) sits on one of the largest $\left(c .600 \mathrm{~km}^{2}\right.$ ) and thickest (up to $250 \mathrm{~m}$ ) tufa deposits in the world (Glover and Robertson 2003) (Figure 10.16a). These workers argue that this large tufa complex was deposited in a large tectonically controlled basin between c.2 and 1.5 million years BP within a series of small lakes when the karstic springs were much more active than at present. The Antalya tufa is composed of pure low-Mg calcite and this is typical of cool-water tufas in the Mediterranean region. Tectonic uplift of the tufa mass created an upper $300 \mathrm{~m}$ terrace and glacio-eustatic sea-level change in the Early to Middle Pleistocene created a lower terrace (c.100$200 \mathrm{~m}$ a.s.l.). Subsequent fluvial activity has cut deep gorges in the tufa and the coastal sections have been eroded by wave action (Glover and Robertson 2003). Thus, the present landscape is the product of complex interactions between a wide range of karstic and nonkarstic geomorphological processes and materials over the last two million years or so. In many places the surface of the tufa is crusted and displays complex secondary karst forms following dissolution and recementation of the tufa deposits (Glover and Robertson 2003). In many areas deep terra rossa type soils have developed.

The deposition of secondary carbonates may form cemented alluvial gravels. These are widespread in Mediterranean karst environments and the 

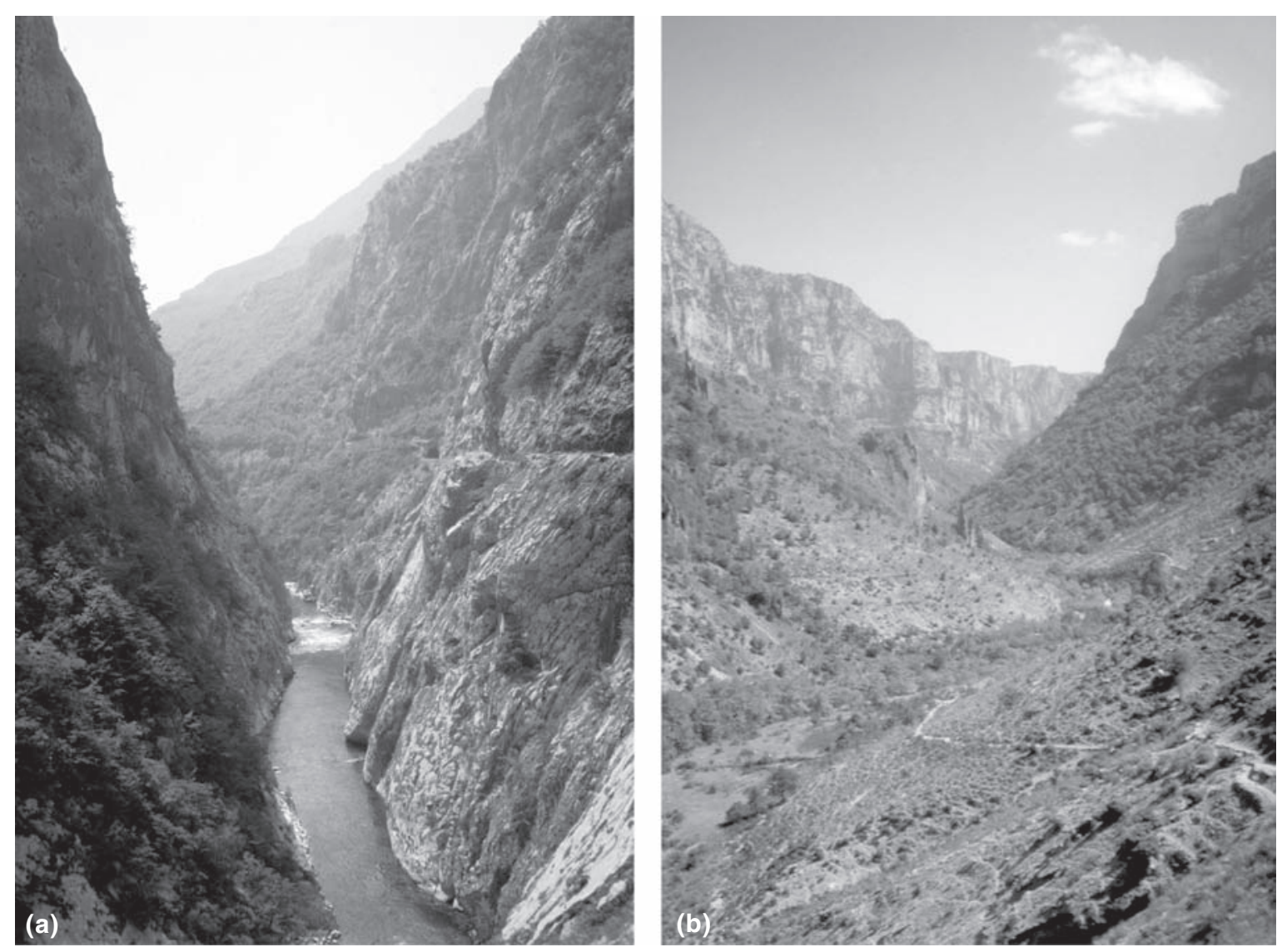

Fig. 10.14. Two limestone gorges at different stages of development in the Mediterranean region. Both are the product of fluvial incision and subaerial weathering of the bedrock cliffs. (a) The Moracha Canyon in Montenegro and (b) the Vikos Gorge in north-west Greece (photos: Jamie Woodward).

best-developed records are typically Pleistocene in age (Vita-Finzi 1969; Hamlin et al. 2000; Macklin et al. 2002; Woodward et al. 2008). This can help preserve the alluvial record and has allowed the development of long-term records of Pleistocene river behaviour through the application of uranium-series dating methods (Chapter 11). Figure 10.16b shows a section in over $20 \mathrm{~m}$ of cemented Pleistocene alluvial gravels in one of the wider reaches of the Moracha Canyon in Montenegro to the north of Podgorica (Figure 10.1).

Ambient temperature deposited carbonates in streams have led to the formation of tufa barrages, cascades, or sheets. These can be impressive and deposition can take place above growing barriers, as in the case of the River Krka in Croatia where there is an alluvial plain above the 20-m high Topolje Falls (Jennings 1985), whilst the
River Korana is divided into sixteen separate lakes along a 12-km gorge at Plitvice (Figure 10.1).

Thermogene travertines are developed, again spectacularly, in Turkey at Pamukkale, at the Roman city of Hierapolis where $35-39^{\circ} \mathrm{C}$ waters emerge at the surface to form a very distinctive topography (Figure 10.16c). The thick travertines at Bagni de Tivoli near Rome have been quarried for over 2,000 years. Travertine, along with marble, was widely used as a building material in Classical Rome because it is strong yet relatively light due to its open texture. These carbonate rocks represent the foundation and essence of classical architecture. Pentecost (1995) provides a useful catalogue of both ambient-temperature and thermogene deposits in Europe and Turkey, whilst sites in Mediterranean North Africa are discussed by Ford and Pedley (1996). 


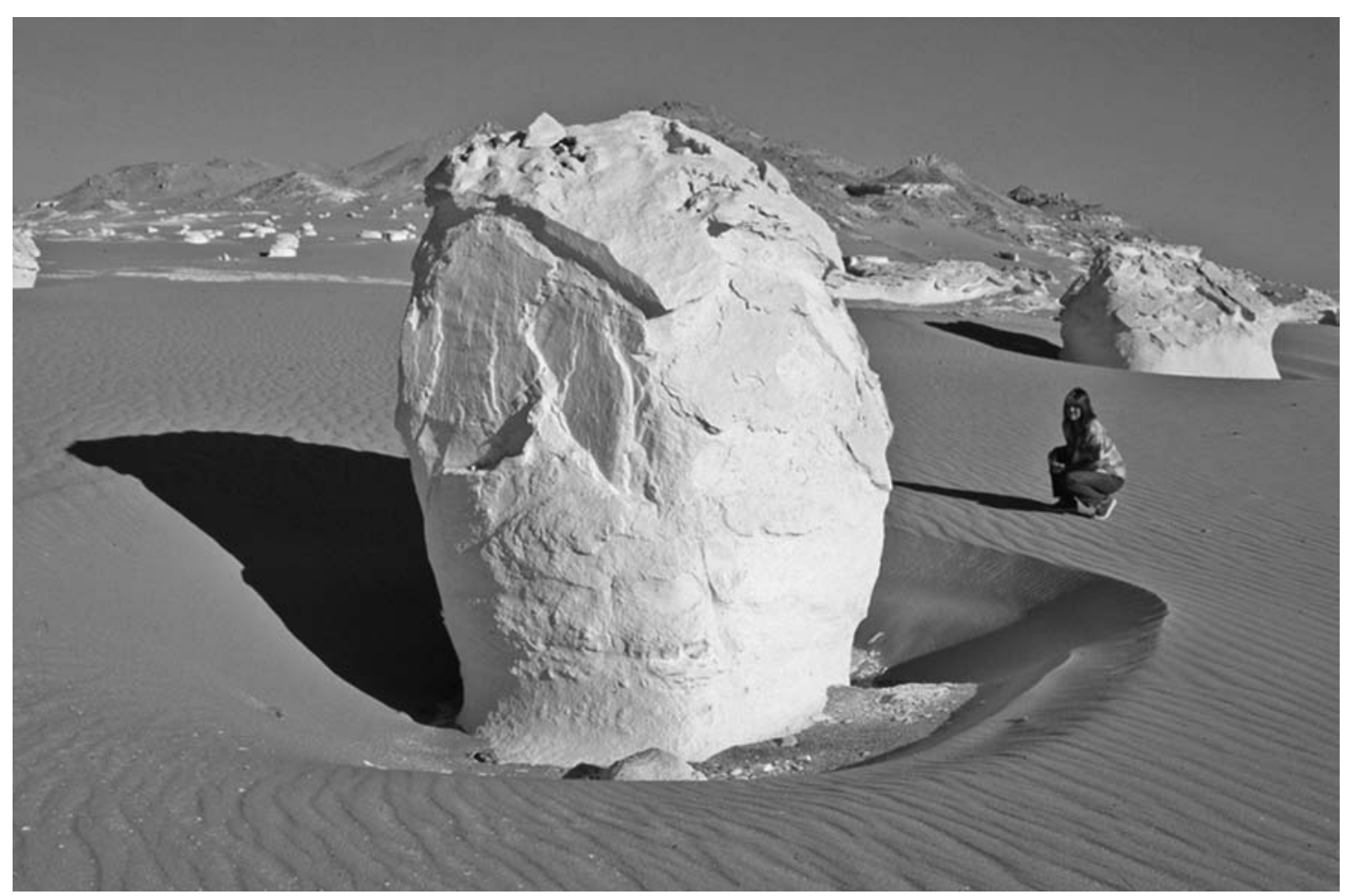

Fig. 10.15. Relict karst pinnacles in the White Desert of Egypt (photo: Tony Waltham).

\section{Karst Systems and Environmental Change}

Given the marked environmental changes that took place in the Mediterranean region during the Pleistocene and Holocene (Chapters 2, 4, 9, 11, and 12), it is clear that karst morphogenesis has been considerably affected by factors other than the autogenic effects so far discussed as, for example, in the cave evolution model presented in Figure 10.7. In broad terms, it is possible to identify four major environmental changes that have impacted upon the karst systems of the region.

First, the elevation and exhumation of limestone surfaces, river basin evolution, and karst development have proceeded alongside continuing tectonic activity in the Mesozoic and Cenozoic eras (e.g. Harvey and Wells 1987; Chapter 1) and, initially, under a climate warmer than present (Chapter 4). In southern France, bauxite deposits (named from the cave-ridden spur of Les Baux) were created by karst weathering even before submergence in a Late Cretaceous sea (Ager et al. 1980).

Second, the availability of relief has varied, both in response to eustatic Quaternary sea level change (of the order of $120 \mathrm{~m}$ ) and earlier in response to the remarkable Messinian (Late Miocene) drying of the Mediterranean Sea basin (Hsü 1972; Adams et al. 1977), when regional base levels fell by more than 1,000 m (Chapter 1). Limestone areas that are now coastal, or near to sea level, were elevated above the littoral zone during the Messinian Salinity Crisis and, repeatedly, during Pleistocene cold-stage low sea-level stands. This means that karst forms are now 'drowned' deep in the vadose zone. Recently, Bakalowicz et al. (2003) have considered the development of the deep karst aquifers in the Mediterranean coastal zone that formed during the Late Miocene Messinian Salinity Crisis around 5.5 Ma. The sea-level fall during this period led to the development of large canyons in the lower reaches of the major river systems. This base level fall also led to the formation of very deep karst systems that lie well below present sea levels. The residence time of the groundwaters stored in these deep coastal karsts is not known. These deep karst aquifers have very long vertical conduits and are unique to the Mediterranean region (Mocochain et al. 2006; Bakalowicz et al. 2008). From a resource management perspective, it is important to establish 

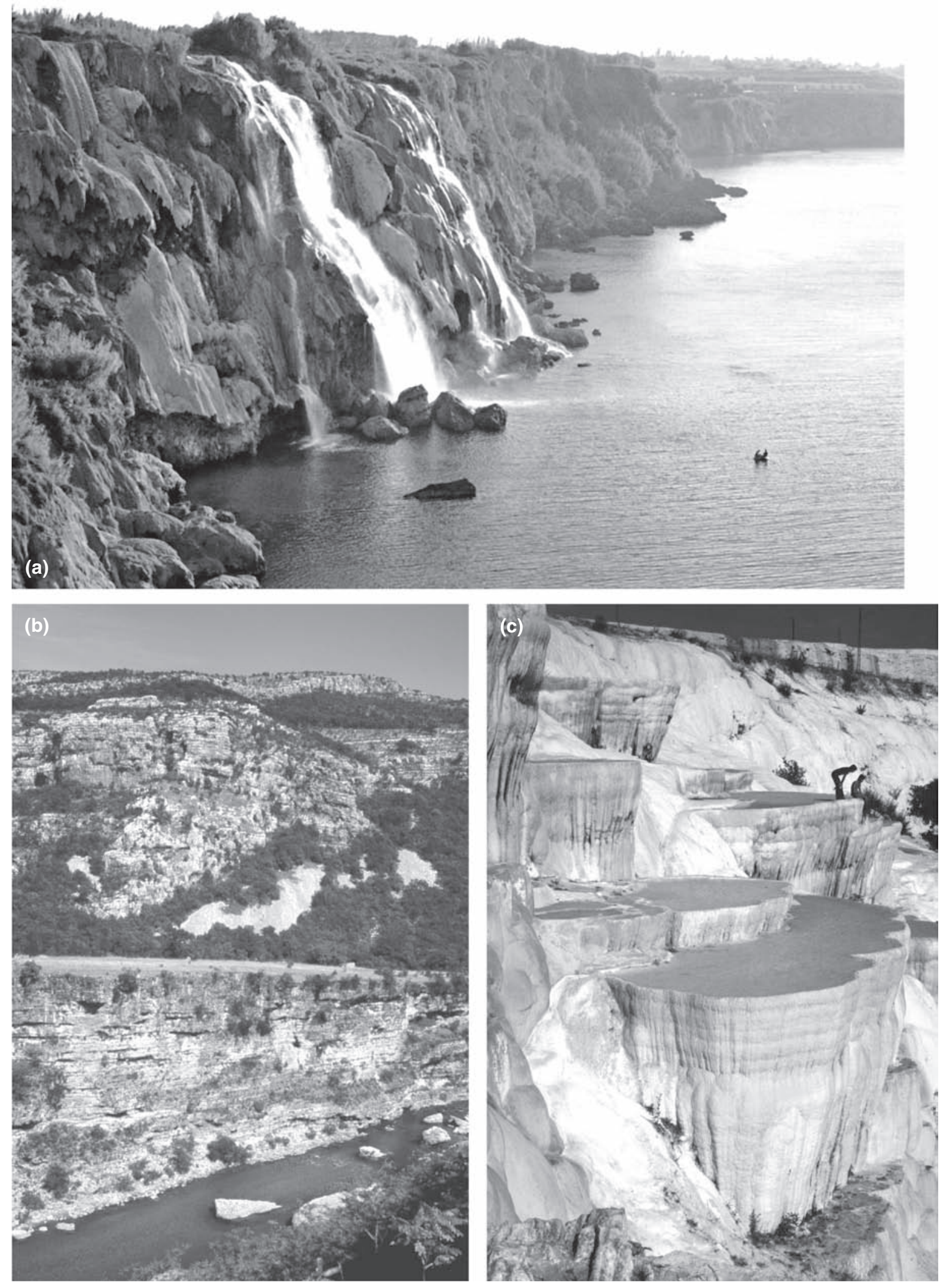


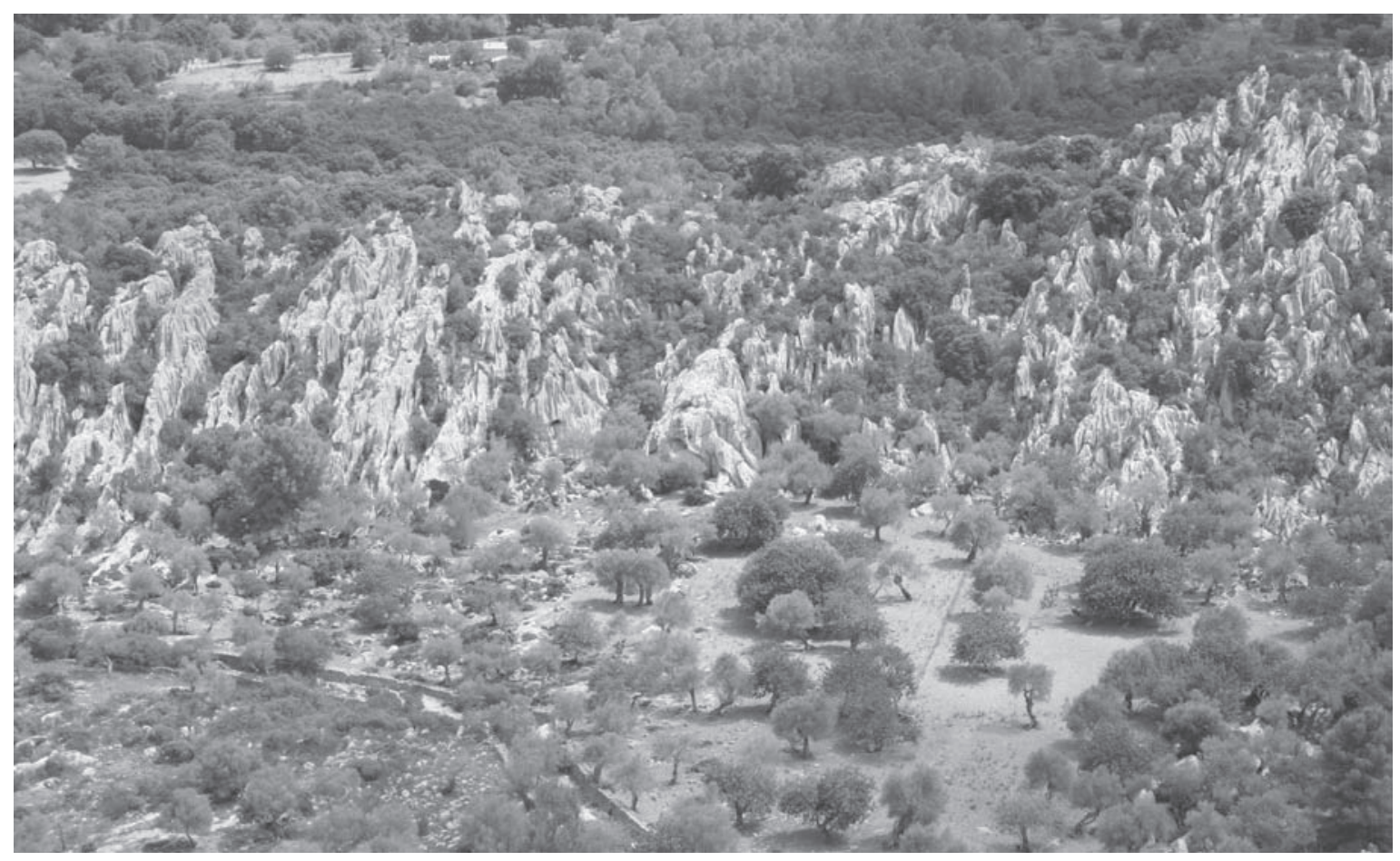

Fig. 10.17. Karst terrain in north-east Majorca showing bare limestone slopes and thick terra rossa soils on the valley floor (photo: Jamie Woodward).

their water resource potential and their role in the contemporary hydrological cycle. Bakalowicz et al. (2003) have discussed the hydrogeological significance of these deep aquifer systems and the difficulties involved in monitoring submarine karst springs and the dynamics of freshwater and sea water exchange in the deep phreatic zone. In Dalmatia these springs are known as vrulje and they have been reported from around the Mediterranean coastal karst. Fleury et al. (2008) monitored the behaviour of two submarine outlets from a karstic system in southern Spain during the 1999-2000 hydrological year. One of the conduits was highly responsive to rapid infiltration across the terrestrial catchment during highintensity rainfall events.

Fig. 10.16. (opposite) Three landscape features in the Mediterranean produced by the precipitation of secondary carbonates. (a) The coastal cliffs in tufa deposits at Anatalya on the southern coast of Turkey. (b) A 20-m exposure in cemented alluvial gravels of Pleistocene age in the lower reaches of the Moracha River in Montenegro. (c) The dramatic pools and slopes at Pamukkale in south-west Turkey. All locations are shown on Figure 10.1. (Photos: (a) and (c), Tony Waltham; (b), Jamie Woodward).
Third, the effects of Pleistocene climate fluctuations have been superimposed upon the broad framework of tectonic activity across the region to impose, in very general terms, a series of wet/dry and cold/warm phases on karstic systems (Chapters 2, 4, 11, and 12). These shifts in Quaternary climate altered the balance between physical and chemical weathering in limestone areas, with more intense physical weathering (and in places more extensive cirque and valley glaciation) of exposed upland limestones during cold episodes (Chapter 12). Thus cliff weathering in many limestone gorges produced Pleistocene talus slopes and boulder-bed streams in excess of those generated by cliff collapse and rockfall today. Lithological and mineralogical analysis of Pleistocene alluvial materials suggests much greater incorporation of physical weathering products in cold phase deposits than later (Lewin et al. 1991; Woodward et al. 1992). The Quaternary also involved periods of higher and lower water tables, so that valley networks and river reaches, and cave systems that are now dry were being actively developed by flowing water. Groundwater bodies beneath some of the desert areas of North Africa were 
TABLE 10.3. Characteristics of active karst settings and passive karst settings for rockshelter and cave entrance environments in limestone terrains

\section{Active Karst Setting}

- Linked to an internal cavern or conduit system

- Dripping vadose waters

- Seasonal water flows and ponding

- Range of hydrological pathways

- Precipitation of calcite and other minerals

- Inwashing of fine sediments via conduits in the host bedrock

- Development of vegetation within the site

- Mineralization of macroscopic plant remains

- Strong chemical diagenesis and mineral alteration

- Humidity may encourage host rock breakdown by frost action

- Evidence of erosion and sediment removal by invasive karst waters

Passive Karst Setting

- No significant links with an internal conduit system

- Dry site without flowing or dripping water

- Limited inwashing of sediments via karstic cavities

- Highly localized or no chemical precipitation

- Limited vegetation growth in the site

- Desiccation of macroscopic plant remains

- Limited chemical diagenesis and mineral alteration

- Import of fine sediments through the shelter opening may be dominant

- Limited host rock weathering by solution

- Subaerial processes are dominant

Note: See Fig. 10.8. Sites may shift between these two end-members in response to climate change.

Source: Modified from Woodward and Goldberg (2001).

developed under more humid Pleistocene conditions, so that they now constitute a fragile, fossil resource that is not effectively being replenished.

Fourth, the removal of a soil and vegetation cover, particularly following human activity during the course of the Holocene (Chapters 6 and 9), has transformed karst systems. Thus deep weathering forms developed under a soil cover (known as rundkarren and generally of rounded form with residual core stones) have become exposed on the surface to form small-scale landscapes of pinnacles, blocks, and chasms as shown in the karst terrain of central Majorca in Figure 10.17. These terrains may be modified by the development of sharp-edged flutes (rillenkarren) and channels (rinnenkarren) produced subsequently by the effects of subaerial solution on bare limestone surfaces. Thus some karst features may be composite forms that owe their origin to a combination of different climatic episodes (and associated process regimes involving exhumation and/or burial by Quaternary sediments) just as cave systems may develop under different phases of water flow and chemical balance (Figures 10.7 and 10.8). Complex surface topography, with a combination of relict and active forms, may have an exposed local relief of the order of $10 \mathrm{~m}$, as in the 'roches ruiniformes' of the French Causses or the 'cuidad encantada' of the Sierra delibar in southern Spain.

\section{Archives of Environmental Change \\ Sediments in Limestone Rockshelters and Cave-mouth Environments}

Caves and rockshelters are found wherever hard limestones are present in the Mediterranean basin. Most deep caves owe their formation to karstic processes to a greater or lesser extent, while some shallow rockshelters may result from non-karstic processes such as fluvial erosion and undercutting, or physical weathering of a gorge wall, for example. In the same way the sediments that accumulate in cave-mouth and rockshelter settings will commonly represent some combination of karstic and non-karstic processes-although, in practice, the division is not always clear cut. Woodward and Goldberg (2001) have used the geomorphological and hydrological characteristics of cave-mouth and rockshelter environments to describe active karst settings and passive karst settings (Table 10.3), because the local context is a very important control on the nature of the accumulating sediment.

Caves and rockshelters in the Mediterranean have provided shelter for both animals and humans throughout much of the Quaternary and they represent a major archaeological resource. Most of the work on the clastic sedimentary records in rockshelter and cave-mouth environments has been carried out as part of archaeological excavations of Palaeolithic and Mesolithic records (ibid.). Figure 10.18 illustrates the wide range of processes that can transport fine-grained sediments to rockshelter and cave mouth environments in karst settings (Woodward and Bailey 2000). It is also important to appreciate, however, that these processes

Fig. 10.18. (opposite) Rockshelter and cave entrance environments can form important sediment sinks and they represent a major archaeological resource. (a) The opening of Asprochaliko rockshelter in the Louros Valley of north-west Greece. This site contains evidence of Middle and Upper Palaeolithic occupation and was excavated by Eric Higgs and his team in the 1960s (photo: Jamie Woodward). (b) Schematic cross-section of a Mediterranean limestone rockshelter showing the processes that can deliver fine sediments to the site and the natural and archaeological materials that can be used for radiometric dating (based on Woodward and Bailey 2000, and Schwarz and Rink 2001). The allogenic (external) sediment sources are shown in white boxes and the autogenic (internal) ones are shown in the shaded box. Compare to Figure 10.8 and Table 10.3. 

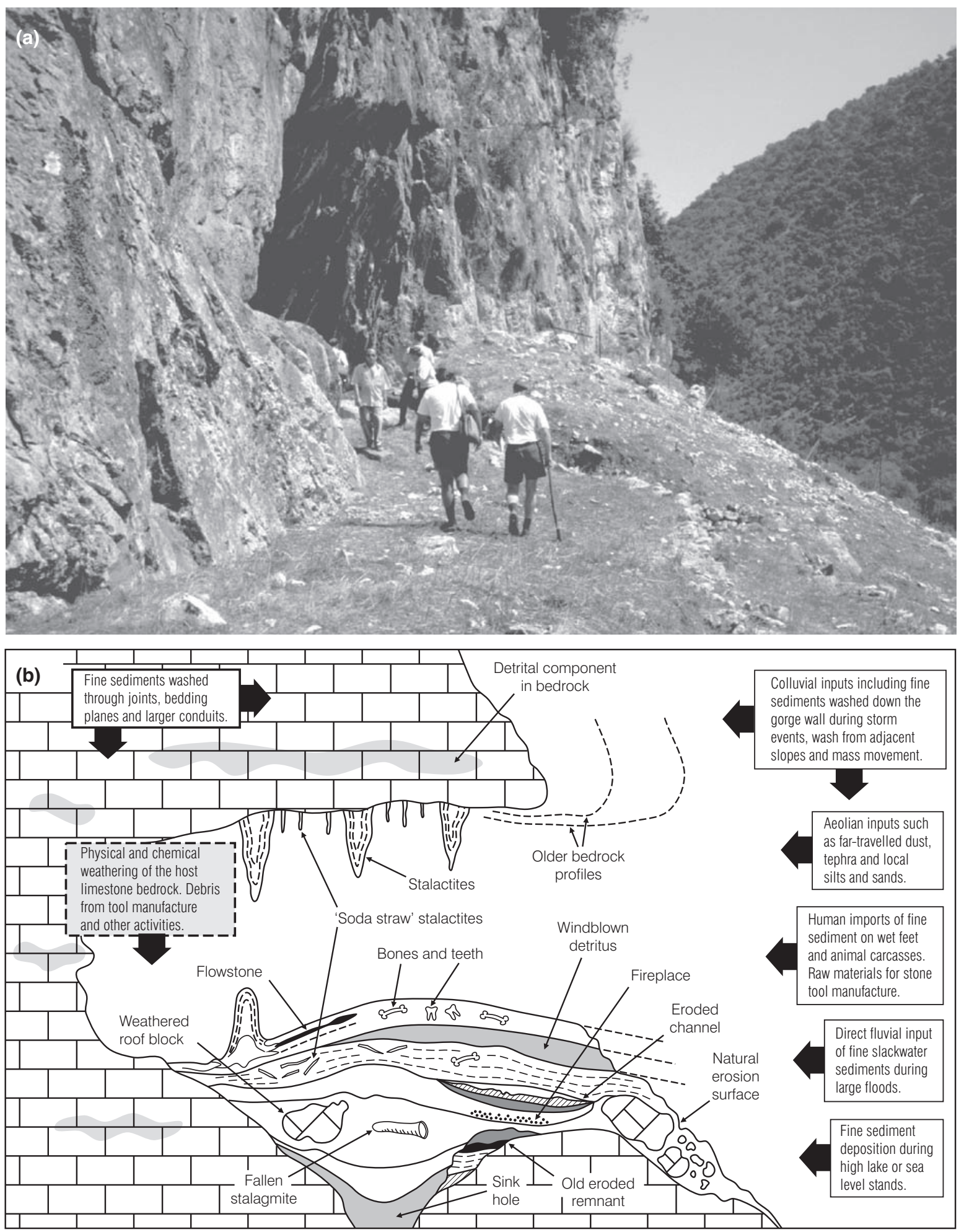
can also be destructive and may remove parts of the sedimentary record. Gaps in the record may also represent periods of non-deposition. In the case of Franchthi Cave in southern Greece, for example, Farrand (2000) points out that at least half the interval between c.26,850 and 6,000 cal. years BP is not represented by any deposits in the excavated parts of the site. Thus, detailed dating programmes are needed to establish the timeframe and chronological resolution of the sedimentary record (Bailey and Woodward 1997; Schwartz and Rink 2001).

Despite the poor stratigraphic resolution of some sites in comparison to other depositional environments, limestone caves and rockshelters commonly contain a range of materials that can be dated (Figure 10.18). These include materials produced by human activity (e.g. charcoal fragments and burnt flints in hearths), karstic processes (speleothems), and allogenic sediments introduced by natural processes (e.g. tephras and aeolian sands). All these materials can be dated using modern scientific methods and these are summarized in Figure 10.18. The use of large-format thin sections to study the microstratigraphy of these deposits has allowed detailed reconstructions of site formation processes (e.g. Goldberg and Bar-Yosef 1998) and recent work on sediment source identification has allowed these records to be placed in their broader geomorphological context (e.g. Woodward et al. 2001).

\section{Speleothems and Quaternary Palaeoclimates}

Recent work on speleothems from karstic caves in Israel has provided excellent high resolution records of climate change for the eastern Mediterranean region (BarMatthews et al. 1999, 2000, 2003). Soreq Cave is located west of Jerusalem and around $40 \mathrm{~km}$ from the Mediterranean Sea (Figure 10.1). It lies close to the modern $500 \mathrm{~mm}$ isohyet at about $400 \mathrm{~m}$ above sea level. The speleothems from Soreq Cave and from Peqiin Cave in the north of Israel have yielded a continuous and high resolution record of karstic processes and climate change spanning the last 250,000 years (Figure 10.19). The carbonate materials have been dated using high precision uranium-series methods. These records match closely with the marine oxygen isotope record and have demonstrated that many features of the climate record for the last cold stage in the North Atlantic (such as Heinrich Events) also impacted upon the eastern Mediterranean region (Bar-Matthews et al. 1999) (Chapters 2 and 4).
The caverns in these semi-arid karst landscapes are highly sensitive environmental systems that are well coupled to changes in temperature and precipitationalthough it is important to point out that a full understanding of the contemporary karst hydrology is needed before the palaeoclimatic record can be fully appreciated (ibid.). A very significant feature of recent work on the speleothem records in Israel has been the exploration of linkages between the high resolution speleothem data and the marine records from the eastern Mediterranean Sea (Bar-Matthews et al. 2003). This research has shown that some periods of sapropel formation were associated with enhanced precipitation across the eastern Mediterranean region. Sapropels are dark, organic-rich horizons that formed periodically on the bottom of the Mediterranean Sea, and are discussed in Chapter 2.

Information on Pleistocene and Holocene sea-level change can also be obtained from speleothems where they have developed in caverns in coastal karst systems that are submerged during high sea-level stands (Chapter 13).When these caverns become flooded by sea water, speleothem growth is halted and they become covered with marine biogenic overgrowths (Surić et al. 2005). These overgrowths can be dated by radiocarbon to provide geochronologies for the timing of cavern flooding by sea water although the precise timing of inundation may be conditioned by the geomorphological setting and local karst hydrology. At some sites flooding is by fresh groundwater as local water tables rise in accordance with sea-level rise. Thus, cavern shape and elevation, groundwater conduit gradients, and cavern distance from the coast are important factors in site selection. Surić et al. (2005) present data from three submerged caves along the Croatian coast where eight speleothems (ranging from 38.5 to $17 \mathrm{~m}$ below present mean sea level) were sampled. Speleothem deposition took place in these caves during the last cold stage between c.37,000 and 22,000 years BP (when global sea levels were around $120 \mathrm{~m}$ lower than present). These workers have produced a sea-level curve for the Late Pleistocene and Holocene that is in broad agreement with work on the Tyrrhenian coast of Italy and the Mediterranean coast of France. Similarly, Bard et al. (2002) have estimated interglacial (MIS 7) sea levels from speleothems preserved in Argentarola Cave in Italy.

\section{The Conservation of Karst Environments}

Today, worldwide academic interest in these karst environments must also be coupled with an appreciation of the value and fragility of Mediterranean karst 


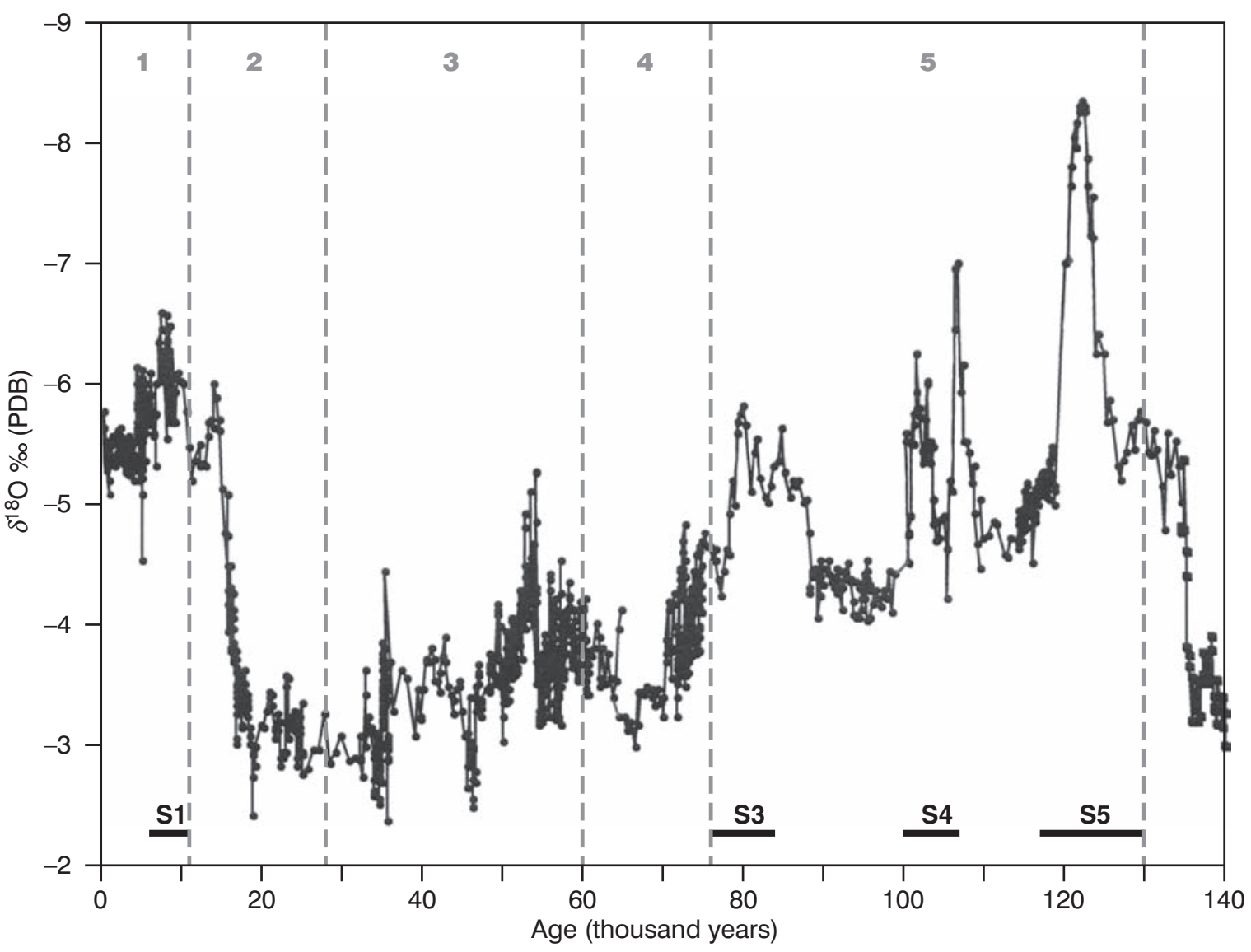

Fig. 10.19. A high-resolution oxygen isotope record $\left(\delta^{18} \mathrm{O}\right)$ from speleothems in Soreq Cave, Israel, spanning the last 140,000 years (modified from Bar-Matthews et al. 1999). This record shows how the regional climate has fluctuated between warmer and wetter periods (peaks) to cooler and drier periods (troughs). It also shows that climate change can be abrupt (see Chapters 4, 9, and 11). Marine oxygen isotope stages 1-5 are shown along with sapropels S1, S3, S4, and S5. Sapropel formation in the eastern Mediterranean Sea is discussed in detail in Chapter 2.

landscapes and groundwater resources (Plagnes and Bakalowicz 2002; Bakalowicz et al. 2008). The conservational aspects of limestone and karsts in the region is attracting increasing attention (Gams et al. 1993). This includes threats to groundwater quality by pollution (both point and diffuse sources and waste disposal) and the potentially damaging exploitation of fossil groundwaters, the destruction of valued landscapes and archaeological sites by quarrying, and by urban/recreational development and land use pressure (Figure 10.20). Karstic lakes are often ecologically important sites but are susceptible to eutrophication and habitat degradation (Reed et al. 2008). There are numerous examples of the unwise use of subsurface water systems which have not been adequately understood, but which have suffered from pollution or resource depletion. Action to protect aquatic environments by the European Commission has involved vulnerability and risk assessment of carbonate (karst) aquifers.

The exploitation of limestone terrains is nothing new-as shown by the huge Carrara marble quarries in Italy that were a resource for Renaissance art and architecture-but the scale of recent transformations is unprecedented. Population pressure and the large number of tourists visiting underground cave systems can also threaten cave environments (including their atmosphere, flora, and fauna) without access management. Limestone caves and rockshelters also 
314 John Lewin and Jamie Woodward

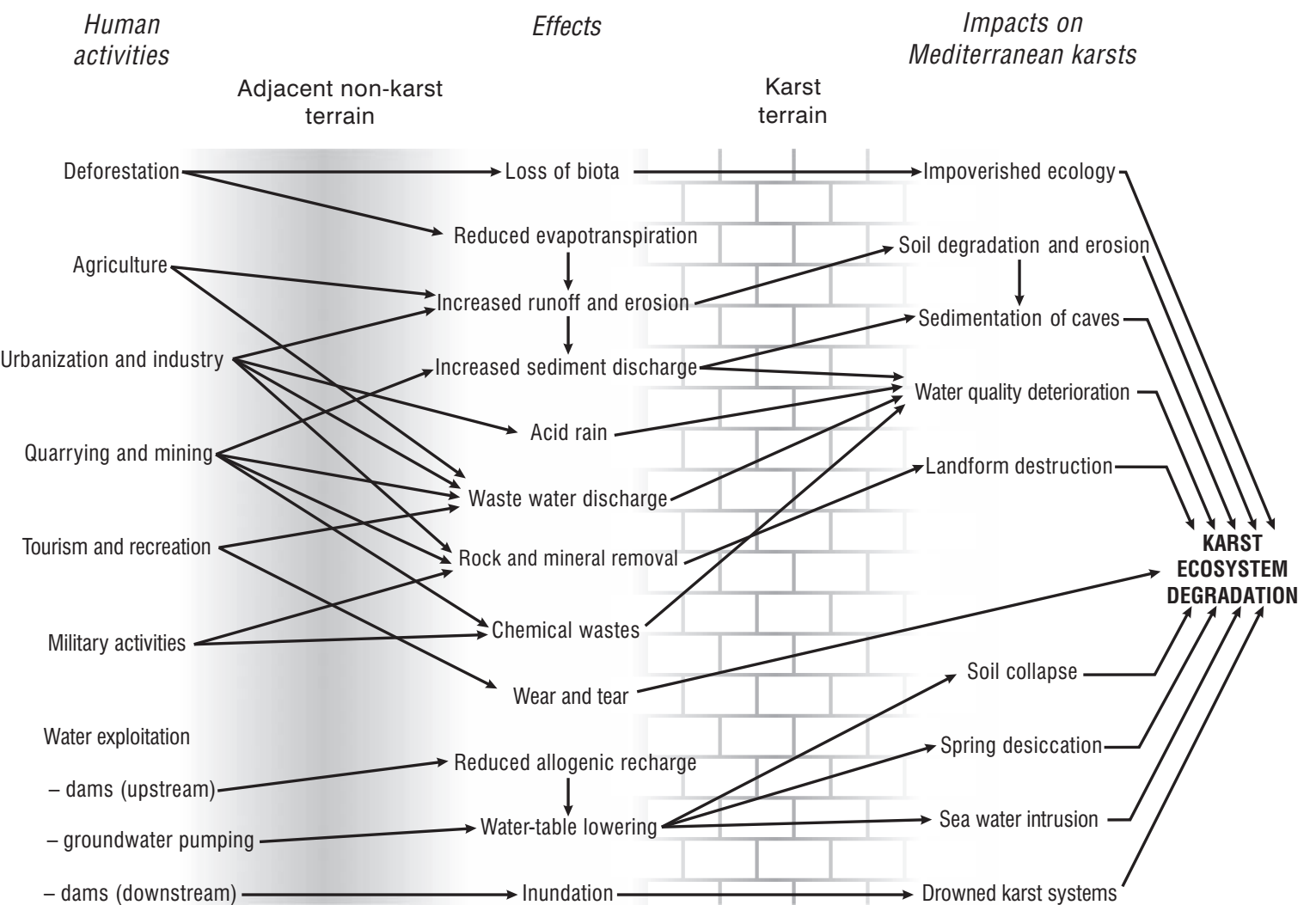

Fig. 10.20. Human activities in the Mediterranean region and their potential impact on non-karst and karst terrains (modified from Williams 1993).

TABLE 10.4. Karst sites in the Mediterranean region with World Heritage status

\begin{tabular}{lll}
\hline Country & \multicolumn{1}{c}{ Karst environment } & \multicolumn{1}{c}{ Designation } \\
\hline Croatia & Plitvice Lakes National Park & Natural Heritage \\
France and Spain & Pyrenees-Mount Perdu & Natural and Cultural \\
Slovenia & Škocjan Caves & Natural Heritage \\
Spain & Altimera Cave & Cultural Heritage \\
& Atapuerca Cave & Cultural Heritage \\
Turkey & Pamukkale & Natural and Cultural \\
Montenegro & Durmitor National Park & Natural Heritage \\
\hline
\end{tabular}

Source: Modified from Hamilton-Smith (2004).

preserve valuable records of Quaternary environmental change that include a rich archaeological resource on the history of Palaeolithic and Mesolithic cultures in particular. Limestone caves in the Mediterranean regionincluding Altimira Cave in Spain and Chauvet in France (Figure 10.1) — contain some of the best-known examples of Upper Palaeolithic cave art and these also require careful conservation and management. A recent and very positive development has been the designation of World Heritage Site status by UNESCO for several karst and cave sites in the Mediterranean region and these are listed in Table 10.4.

\section{Conclusions}

Karst terrains are a very significant component of the physical geography of the Mediterranean basin because the effects of both carbonate dissolution and precipitation processes are widespread. It can be argued that carbonate rocks are an important unifying feature of much of the Mediterranean basin. Many of the key mountain ranges such as the Pindus Mountains of Greece, the Apennines of Italy, and the Dinaric Alps of the former Yugoslavia are dominated by uplifted limestone terrains and these landscapes include glaciokarsts, deep 
limestone gorges, large dolines, sinking streams, and extensive cave systems. Limestone bedrock coasts are also a key feature of the Mediterranean environment (Chapter 13). Much of the river water that flows into the Mediterranean Sea has passed through karst terrain, so this environment is an important influence on both river regimes and water quality (Chapter 8 ).

Karst landscapes pose particular engineering problems and ground collapse can be a significant geohazard in many areas. Karst also leads to the formation of distinctive red terra rossa soils (Chapter 6) and vegetation communities and it has influenced the development of agricultural practices and water resource management strategies for thousands of years. In some parts of the Mediterranean region-particularly those in North Africa - the karsts have yet to be fully explored. This is reflected in the much smaller literature on the karsts of several countries including Libya, Algeria, and Tunisia, for example (see entries in Gunn 2004). An understanding of karstic processes is essential for many disciplines and may provide insights in unexpected contexts. For example, recent work at the Early Bronze Age fortified site of Vayia, in southern Greece, has shown that the variable development and orientation of karren features on limestone blocks found within cairns could be used to establish a relative dating framework for architectural remains and to establish that the cairns themselves were formed in antiquity (Tartaron et al. 2006).

It is also important to appreciate the significance of carbonate precipitation dynamics in the karst systems of the region. The formation of tufa, travertine, speleothems, and calcrete is also a key feature of Mediterranean karst environments and this has produced a highly distinctive suite of karstic features and landscapes. The Mediterranean basin contains some of the most extensive and spectacular Pliocene- and Quaternary-age tufa deposits in the world (Glover and Robertson 2003) including the distinctive terrains at Pamukkale and Plitvice. Carbonate precipitates often constitute important archives of Quaternary environmental change that can be dated by uranium-series methods. This approach has provided new insights into the Pleistocene glacial record in the Mediterranean and recent work on speleothems in Israel, in particular, has produced very detailed and globally significant records of environmental change for the last 250,000 years (e.g. Bar-Matthews et al. 2003). Mediterranean karst landscapes have been shaped by a range of spatially and temporally variable environmental fluctuations in the recent geological past. In broad terms these reflect the variable impacts of long-term tectonic history and Quaternary climate change and, in the Holocene, the increasing intensity of human activity across the basin from Neolithic to modern times.

\section{References}

Adams, C. G., Benson, R. H., Kidd, R. B., Ryan, W. B. F., and Wright, R. C. (1977), The Messinian salinity crisis and evidence of late Miocene eustatic changes in the world ocean. Nature 269: 383-6.

Ager, D. V. (1980), The Geology of Europe. McGraw Hill, London. Albritton, C. C., Brooks, J. E., Issawi, B., and Swedor, A. (1990), Origin of the Qattara Depression, Egypt. Bulletin of the Geological Society of America 102: 952-60.

Bailey, G. N. and Woodward, J. C. (1997), The Klithi deposits: sedimentology, stratigraphy and chronology, in G. N. Bailey (ed.), Klithi: Palaeolithic Settlement and Quaternary Landscapes in Northwest Greece, i. Excavation and Intra-site Analysis at Klithi. Cambridge, McDonald Institute for Archaeological Research, 61-94.

— Turner, C., Woodward, J. C., Macklin, M. G., and Lewin, J. (1997), The Voidomatis basin: an introduction, in G. N. Bailey (ed.), Klithi: Palaeolithic Settlement and Quaternary Landscapes in Northwest Greece, i. Klithi in its Local and Regional Setting. Cambridge, McDonald Institute for Archaeological Research, 321-45.

Bakalowicz, M., Fleury, P., Jouvencel, B., Promé, J. J., Becker, P., Carlin, T., Dörfliger, N., Seidel, J. L., and Sergent, P. (2003) Coastal karst aquifers in Mediterranean regions: a methodology for exploring, exploiting and monitoring sub-marine springs. Tecnologia de la Intrusion de Agua de Mar en Acuiferos Costeros: Paises Mediterraneos. IGME, Madrid.

El Hakim, M., and El-Hajj, A. (2008), Karst groundwater resources in the countries of eastern Mediterranean: the example of Lebanon. Environmental Geology 54: 597-604.

Bard, E., Antonioli, F., and Silenzi, S. (2002), Sea-level during the penultimate interglacial period based on a submerged stalagmite from Argentarola Cave (Italy). Earth and Planetary Science Letters 196: 135-46.

Bar-Matthews, M., Ayalon, A., Kaufman, A., and Wasserburg, G. J. (1999), The Eastern Mediterranean palaeoclimate as a reflection of regional events: Soreq cave, Israel. Earth and Planetary Science Letters 166: 85-95.

(2000), Timing and hydrological conditions of Sapropel events in the Eastern Mediterranean, as evident from speleothems, Soreq cave, Israel. Chemical Geology 169: 145-56.

Ayalon, A., Gilmour, M., Matthews, A., and Hawksesworth, C. (2003), Sea-land oxygen isotopic relationships from planktonic foraminifera and speleothems in the Eastern Mediterranean region and their implication for paleorainfall during interglacial intervals, Geochimica et Cosmochimica Acta, 67: 3181-99.

Beckinsale, R. P. and Chorley, R. J. (1991), The History of the Study of Landforms or the Development of Geomorphology 1890 to 1950. New York, Routledge.

Biju-Duval, B., Dercourt, V., and Le Pichon, X. (1977), From the Tethys ocean to the Mediterranean sea: a plate tectonic model of the evolution of the western Alpine system, in B. Biju-Duval and L. Montadert (eds.), The Structural History of the Mediterranean Basins. Éditions Technip, Paris, 143-64. 
Bonacci, O., Ljubenkov, I., and Roje-Bonacci, T. (2006), Karst flash floods: an example from the Dinaric karst (Croatia). Natural Hazards and Earth Systems Science 6: 195-203.

Brewster, H. (1997), The River Gods of Greece: Myths and Mountain Waters in the Hellenic World. I. B. Tauris, London.

Calaforra, J. M. and Pulido-Bosch, A. (2003), Evolution of the gypsum karst of Sorbas (SE Spain). Geomorphology 50: $173-80$

Courbon, P. and Chabert, C. (1986), Atlas des Grandes Cavities Mondiales. UIS-FFS.

Cvijić, J. (1893), Das Karstphänomen. Geographische Abhandlungen herausgegeben von A. Penck [Geographical Proceedings. Published by A. Penck] 5/3: 218-329.

Dewey, J. F., Pitman III, W. C., Ryan, W. B. F., and Bonnin, J. (1973), Plate tectonics and the evolution of the Alpine system. Bulletin of the Geological Society of America 84: 3137-80.

Farrand, W. R. (2000), Depositional History of Franchthi Cave: Sediments, Stratigraphy and Chronology: Fascicle 12. Indiana University Press, Bloomington, Ind.

Ferrarese, F., Sauro, U., and Tonello, C. (1998), The Montello Plateau. Zeitschrift für Geomorphologie, Suppl.109: 41-62.

Fleury, P., Bakalowicz, M., de Marsily, G., and Cortes, J. M. (2008), Functioning of a coastal karstic system with a submarine outlet, in southern Spain. Hydrogeology Journal 16: 75-85.

Ford, D. C. (2004), Karst in J. Gunn (ed.), Encyclopedia of Caves and Karst Science. Fitzroy Dearborn, London, 473-5.

and Pedley, H. M. (1996), A review of tufa and travertine deposits of the world. Earth Science Reviews 41: 117-75.

and Williams, P. W. (1989), Karst Geomorphology and Hydrology. Unwin Hyman, London.

Frumkin, A. (1994), Hydrology and denudation rates of halite karst. Journal of Hydrology 162: 171-89.

Gale, S. J. and Hoare, P. G. (1997), The glacial history of the northwest Picos de Europa of northern Spain. Zeitschrift für Geomorphologie, Ns 41: 81-96.

- Gilbertson, D. D., Hoare, P. G., Hunt, C. O., Jenkinson, R. D., Lamble, A. P., O'Toole, C., van der Veen, M., and Yates, G. (1993), Late Holocene environmental change in the Libyan predesert. Journal of Arid Environments 24: 1-19.

Gams, I. (1978), The Polje: The problems of its definition. Zeitschrift für Geomorphologie 22: 170-81.

- Nicod, J., Julian, M., Anthony, E., and Sauro, U. (1993), Environmental change and human impacts on the Mediterranean karsts of France, Italy and the Dinaric region, in P. W. Williams (ed.), Karst Terrains, Environmental Changes, Human Impact. Catena Suppl. 25: 59-98.

Gillieson, D. (1996), Caves: Processes, Development and Management. Blackwell, Oxford.

Glover, C. and Robertson, A. H. F. (2003), Origin of tufa (coolwater carbonate) and related terraces in the Antalya area, SW Turkey. Geological Journal 38: 329-58.

Goldberg, P. and Bar-Yosef, O. (1998), Site formation processes in Kebara and Hayonim Caves and their significance in Levantine prehistoric caves, in T. Akazawa, K. Aoki, and O. Bar-Yosef (eds.), Neandertals and Modern Humans in Western Asia. Plenum, New York, 107-23.

Gunn, J. (2004), Encyclopedia of Caves and Karst Science. Fitzroy Dearborn, London.

Hamilton-Smith, E. (2004), World Heritage Sites, in J. Gunn (ed.), Encyclopedia of Caves and Karst Science. Fitzroy Dearborn, London, 777-9.

Hamlin, R. H. B., Woodward, J. C., Black, S., and Macklin, M. G. (2000), Sediment fingerprinting as a tool for interpreting long- term river activity: the Voidomatis basin, NW Greece, in I. D. L. Foster (ed.), Tracers in Geomorphology. John Wiley \& Sons, Chichester, 473-501.

Harvey, A. M. and Wells, S. G. (1987), Response of Quaternary fluvial systems to differential epeirogenic uplift: Aguas and Feos river systems, southeast Spain. Geology 15: 689-93.

Herak, M. and Stringfield, V. T. (eds.) (1972), Karst: Important Karst Regions of the Northern Hemisphere. Elsevier, Amsterdam, 551.

Hodge, E. J., Richards, D. A., Smart, P. L., Andreo, B., Hoffmann, D. L., Mattey, D. P., and González-Ramón, A. (2008), Effective precipitation in southern Spain (266 to $46 \mathrm{ka}$ ) based on a speleothem stable carbon isotope record. Quaternary Research 69: 447-57.

Hsü, K. J. (1972), When the Mediterranean dried up. Scientific American 227: 27-36.

Hughes, P. D., Woodward, J. C., Gibbard, P. L., Macklin, M. G., Gilmour, M. A., and Smith, G. R. (2006), The glacial history of the Pindus Mountains, Greece. Journal of Geology 114: 413-34.

Jakucs, L. (1977), Morphogenetics of karst regions. Unwin Hyman, London.

Jennings, J. N. (1985), Karst Geomorphology. Blackwell, Oxford.

Jourde, H., Roesch, A., Guinot, V., and Bailly-Comte, V. (2007), Dynamics and contribution of karst groundwater to surface flow during Mediterranean flood. Environmental Geology 51: 725-30.

King, G., Sturdy, D., and Bailey, G. N. (1997), The tectonic background to the Epirus landscape, in G. N. Bailey (ed.), Klithi: Palaeolithic Settlement and Quaternary Landscapes in Northwest Greece. McDonald Institute, Cambridge, ii. 541-58.

Klimchouk, A. (2004), Morphometry of Caves, in J. Gunn (ed.), Encyclopedia of Caves and Karst Science. Fitzroy Dearborn, London, 524-6.

Lowe, D., Cooper, A., and Sauro, U. (eds.) (1996), Gypsum Karst of the World. International Journal of Speleology (Special Issue) 25: 3-4.

Lewin, J., Macklin, M. G., and Woodward, J. C. (1991), Late Quaternary fluvial sedimentation in the Voidomatis Basin, Epirus, northwest Greece. Quaternary Research 35: 103-15.

Lowry, D. C. and Jennings, J. N. (1974), The Nullabor karst Australia. Z. Geom. 18: 35-81.

Macklin, M. G., Fuller, I. C., Lewin, J., Maas, G. S., Passmore, D. G., Rose, J., Woodward, J. C., Black, S., Hamlin, R. H. B., and Rowan, J. S. (2002), Correlation of Late and Middle Pleistocene fluvial sequences in the Mediterranean and their relationship to climate change. Quaternary Science Reviews 21/14/15: $1633-44$

Milanović, P. T. (2000), Geological Engineering in Karst. Belgrade, Zebra.

Mocochain, L., Clauzon, G., Bigot, J., and Brunet, P. (2006), Geodynamic evolution of the peri-Mediterranean karst during the Messinian and the Pliocene: evidence from the Ardèche and Rhône Valley systems canyons, Southern France. Sedimentary Geology 188/9: 219-33.

Palmer, A. N. (1991), Origin and morphology of limestone caves. Bulletin of the Geological Society of America 103: 1-21.

Pena, J. L., Sancho, C., and Lozano, M. V. (2000), Climatic and tectonic significance of Late Pleistocene and Holocene tufa deposits in the Mijares River canyon, eastern Iberian Range, Northeast Spain. Earth Surface Processes and Landforms 25: $1403-17$. 
Pentecost, A. (1995), The Quaternary travertine deposits of Europe and Asia Minor. Quaternary Science Reviews 14: 100528.

Perritaz, L. (2004), Africa, North in J. Gunn (ed.), Encyclopedia of Caves and Karst Science. Fitzroy Dearborn, London, 13-16.

- and Monbaron, M. (1998), Geomorphological approach to the Aït Abdi Karst Plateau (Central High Atlas, Morocco). Zeitschrift für Geomorphologie 109: 83-104.

Plagnes, V. and Bakalowicz, M. (2002), The protection of a karst water resource from the example of the Larzac karst plateau (south of France): a matter of regulations or a matter of process knowledge? Engineering Geology 65: 107-16.

Reed, J. M., Leng, M. L., Ryan, S., Black, S., Altinsaçli, S., and Griffiths, H. I. (2008), Recent habitat degradation in karstic Lake Uluabat, western Turkey: A coupled limnologicalpalaeolimnological approach. Biological Conservation 141: 2765-83.

Rossi, C. (2004), Picos de Europa, Spain in J. Gunn (ed.), Encyclopedia of Caves and Karst Science. Fitzroy Dearborn, London, 582-5.

Schwarz, H. P. and Rink, W. J. (2001), Dating methods for sediments of caves and rockshelters. Geoarchaeology 16 , 355-71.

Smart, C. C. and Worthington, S. R. H. (2004), Springs, in J. Gunn (ed.), Encyclopedia of Caves and Karst Science. Fitzroy Dearborn, London, 699-703.

Smart, P. L. (1986), Origin and development of glacio-karst closed depressions in the Picos de Europa, Spain. Zeitschrift für Geomorphologie, Ns 30; 423-43.

Smith, B. J., Warke, P. A., and Moses, C. A. (2000), Limestone weathering in contemporary arid environments: a case study from southern Tunisia. Earth Surface Processes and Landforms 25: 1343-54.

Surić, M., Juračić, M., Horvatinčić, N., and Bronić, I. K. (2005), Late Pleistocene-Holocene sea level rise and the pattern of coastal karst inundation: records from submerged speleothems along the Eastern Adriatic Coast (Croatia). Marine Geology 214: 163-75.

Tartaron, T. F., Pullen, D. J., and Noller, J. S. (2006), Rillenkarren at Vayia: geomorphology and a new class of Early Bronze Age fortified settlement in Southern Greece. Antiquity 80: 145-60.

Van Houten, F. B. (1980), Latest Jurassic-Early Cretaceous regressive facies, northeast Africa Craton. American Association of Petroleum Geologists Bulletin 64: 857-67.

Vita-Finzi, C. (1969), The Mediterranean Valleys: Geological Changes in Historical Times. Cambridge, Cambridge University Press.

Waltham, A. C. (1978), The caves and karst of Astraka, Greece. Transacations of the British Cave Research Association 5: $1-12$.
(2001), Pinnacles and barchans in the Egyptian desert. Geology Today 17: 101-4.

White, W. B. (1988), Geomorphology and Hydrology of Karst Terrains. Oxford University Press, Oxford.

Williams, P. W. (1993), Environmental change and human impact on karst terrains: an introduction, in P. W. Williams (ed.), Karst Terrains, Environmental Changes, Human Impact. Catena Suppl. 25: 1-19.

- (2004), Karst Evolution, in J. Gunn (ed.), Encyclopedia of Caves and Karst Science. Fitzroy Dearborn, London, 475-8.

Windley, B. F. (1984), The Evolving Continents. John Wiley \& Sons, Chichester.

Woodward, J. C. (1995), Patterns of erosion and suspended sediment yield in Mediterranean river basins, in I. D. L. Foster, A. M. Gurnell, and B. W. Webb (eds.), Sediment and Water Quality in River Catchments. John Wiley and Sons, Chichester, 365-89.

(1997), Late Pleistocene rockshelter sedimentation at Megalakkos, in G. N. Bailey (ed.), Klithi: Palaeolithic Settlement and Quaternary Landscapes in Northwest Greece, ii. Klithi in its Local and Regional Setting. McDonald Institute for Archaeological Research, Cambridge, 377-93.

and Bailey, G. N. (2000), Terminal Pleistocene sediment sources and geomorphological processes recorded in rockshelter sequences in northwest Greece in I. D. L. Foster (ed.), Tracers in Geomorphology. John Wiley \& Sons, Chichester, 521-51.

- and Goldberg, P. (2001), The sedimentary records in Mediterranean rockshelters and caves: archives of environmental change. Geoarchaeology: An International Journal 16/4: 327-54.

Lewin, J., and Macklin, M. G. (1992), Alluvial sediment sources in a glaciated catchment: the Voidomatis basin, northwest Greece. Earth Surface Processes and Landforms 17/3: 205-16.

Hamlin, R. H. B., Macklin, M. G., Karkanas, P., and Kotjabopoulou, E. (2001), Quantitative sourcing of slackwater deposits at Boila Rockshelter: A record of Lateglacial flooding and Palaeolithic settlement in the Pindus Mountains, Northwest Greece. Geoarchaeology: An International Journal 16/5: 501-36.

Macklin, M. G., and Smith, G. R. (2004), Pleistocene glaciation in the mountains of Greece, in J. Ehlers and P. L. Gibbard (eds.), Quaternary Glaciations - Extent and Chronology, i. Europe Elsevier, Amsterdam, 155-73.

Hamlin, R. H. B., Macklin, M. G., Hughes, P. D., and Lewin, J. (2008), Glacial activity and catchment dynamics in northwest Greece: Long-term river behaviour and the slackwater sediment record for the last glacial to interglacial transition. Geomorphology 101: 44-67.

\section{This chapter should be cited as follows}

Lewin, J. and Woodward, J. C. (2009), Karst geomorphology and environmental change, in J. C. Woodward (ed.), The Physical Geography of the Mediterranean. Oxford University Press, Oxford, 287-317. 
10-Woodward-C10 9780199268030-Jamie-Woodward（Typeset by SPi, Chennai) 318 of 318 April 15, 2009 13:15 